\title{
Temperature and Strain-Rate Effects on Low-Cycle Fatigue Behavior of Alloy $800 \mathrm{H}$
}

\author{
K. BHANU SANKARA RAO, H. SCHIFFERS, H. SCHUSTER, and G.R. HALFORD
}

The effects of strain rate $\left(4 \times 10^{-6}\right.$ to $\left.4 \times 10^{-3} \mathrm{~s}^{-1}\right)$ and temperature on the low-cycle fatigue (LCF) behavior of alloy $800 \mathrm{H}$ have been evaluated in the range $750{ }^{\circ} \mathrm{C}$ to $950{ }^{\circ} \mathrm{C}$. Total axial strain controlled LCF tests were conducted in air at a strain amplitude of \pm 0.30 pct. Low-cycle fatigue life decreased with decreasing strain rate and increasing temperature. The cyclic stress response behavior showed a marked variation with temperature and strain rate. The time- and temperaturedependent processes which influence the cyclic stress response and life have been identified and their relative importance assessed. Dynamic strain aging, time-dependent deformation, precipitation of parallel platelets of $\mathrm{M}_{23} \mathrm{C}_{6}$ on grain boundaries and incoherent ledges of twins, and oxidation were found to operate depending on the test conditions. The largest effect on life was shown by oxidation processes.

\section{INTRODUCTION}

ALLOY $800 \mathrm{H}$ is an iron-based, fully austenitic alloy. It has the same chemical composition as alloy 800 with the exception that the carbon content is restricted to the upper portion of the standard range for alloy 800 . In addition to a controlled-carbon content, alloy $800 \mathrm{H}$ receives an annealing treatment that produces a coarse grain size. The larger grain size and carbon content give this alloy greater creep and rupture strength. The alloy is used as a material for heat-exchanging components in various energy conversion systems and in the petrochemical industry. Resistance to low-cycle fatigue (LCF) and creep-fatigue interaction is an important requirement for the successful design of hightemperature, heat-exchanging components. Low-cycle fatigue loadings are expected to result from thermally induced strain cycles associated with start-up and shutdown and fluctuations in operating conditions. Only limited LCF data are available on alloy $800 \mathrm{H}$ at temperatures higher than 750 ${ }^{\circ} \mathrm{C}$ and at strain rates less than $4 \times 10^{-4} \mathrm{~s}^{-1} .{ }^{[1.2 .3]}$ The majority of the reported tests have been conducted at $\dot{\varepsilon} \approx 10^{-3}$ $\mathrm{s}^{-1}$. This strain rate is orders of magnitude higher than the thermally induced strain rates $\left(\approx 10^{-6} \mathrm{~s}^{-1}\right)$ in heat-exchanging components. There is, therefore, a need for fatigue data at lower strain rates in this high-temperature regime. Here, the fatigue behavior can be affected significantly because of changes in deformation and damage mechanisms caused by differences in slip mode, oxidation, phase and geometrical instabilities, and dynamic strain aging (DSA). The effect of these temperature- and time-dependent processes may reduce an alloy's cyclic life resistance by orders of magnitude as compared to the room-temperature behavior. By studying the failure modes under carefully chosen lab-

K. BHANU SANKARA RAO, on leave from the Indira Gandhi Centre for Atomic Research, Kalpakkam 603102, India, is National Research Council Fellow, NASA Lewis Research Center. H. SCHIFFERS, Head, Mechanical Testing Laboratory, and H. SCHUSTER, Section Head, Mechanical Properties and Corrosion, are with the Institute for Materials in Energy Systems, Juelich D-52428, Germany. G.R. HALFORD, Senior Scientific Technologist, is with the Structures Division, NASA Lewis Research Center, Cleveland, $\mathrm{OH} 44135$.

Manuscript submitted November 17, 1994. oratory conditions, it is possible to obtain deeper insight into the various time-dependent damage processes, their interactions, and the factors controlling their rates of development. More confident extrapolation to the conditions that are not covered by testing should then be possible by employing appropriate life prediction approaches.

The current investigation has been conducted with the following objectives: (a) to study the influence of various time-dependent processes on LCF life and cyclic stress response of alloy $800 \mathrm{H}$ over a range of strain rates at a relatively high temperature of $850^{\circ} \mathrm{C}$; (b) to assess the effects of temperature on LCF behavior between $750^{\circ} \mathrm{C}$ and $950{ }^{\circ} \mathrm{C}$ at a constant strain rate; and (c) to obtain detailed information on crack initiation and propagation modes, precipitation behavior under LCF loading, and micromechanisms of cyclic deformation under the aforementioned conditions. All the LCF tests were performed at a constant axial strain range of $0.60 \mathrm{pct}$ (strain amplitude: $\pm 0.30 \mathrm{pct}$ ).

\section{EXPERIMENTAL PROCEDURES}

Alloy $800 \mathrm{H}$, with the composition (wt pct) $46.38 \mathrm{Fe}$, $31.0 \mathrm{Ni}, 20.55 \mathrm{Cr}, 0.07 \mathrm{Co}, 0.17 \mathrm{Mo}, 0.25 \mathrm{Al}, 0.35 \mathrm{Ti}, 0.06 \mathrm{C}$, $0.85 \mathrm{Mn}$, and $0.32 \mathrm{Si}$, was used in the form of $22-\mathrm{mm}$ diameter solution-annealed rods. Solution annealing was carried out at $1175^{\circ} \mathrm{C}$ for 1 hour followed by water quenching, which produced an average linear intercept grain size of
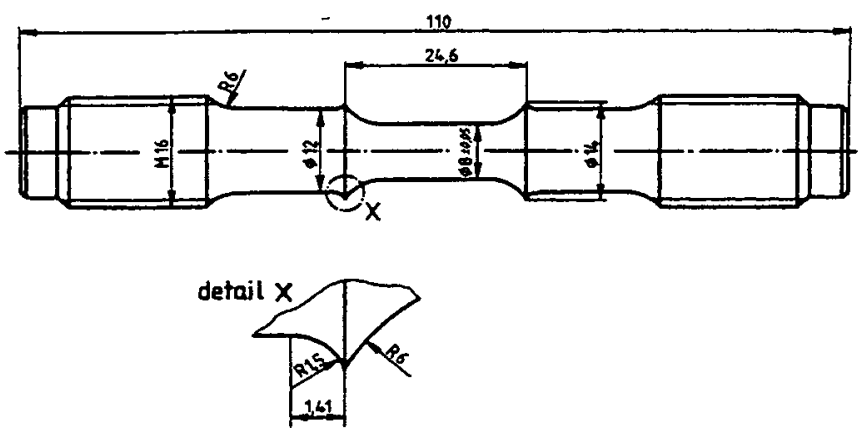

Fig. 1-Geometry of the specimen (all dimensions are in millimeters). 
Table I. Effects of Strain Rate and Temperature on LCF Properties of ALLOY $800 \mathrm{H}$

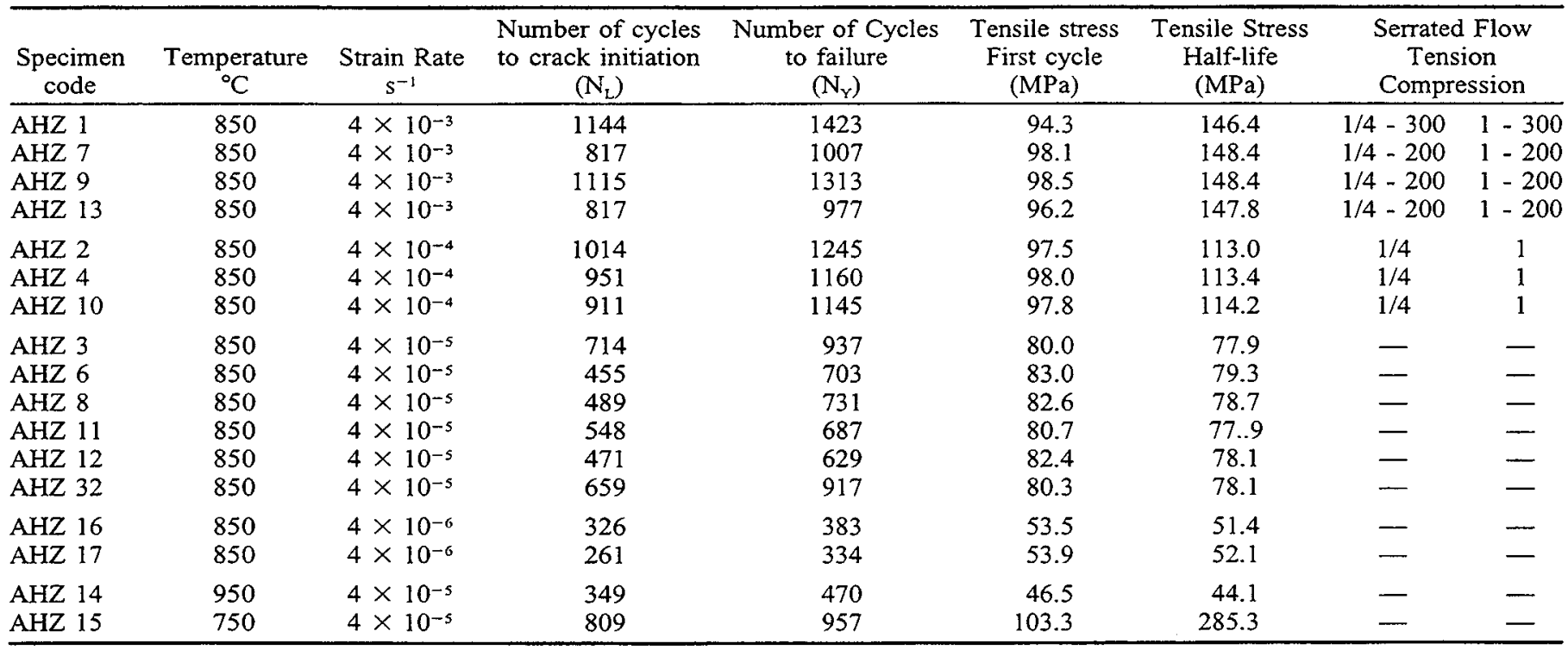

$130 \mu \mathrm{m}$ (ASTM 3). Figure 1 shows the LCF test specimen. Tests were performed in air under fully reversed, axial strain-controlled mode, employing a symmetrical, triangular strain-wave cycle in a servohydraulic system of \pm 100 $\mathrm{kN}$ dynamic load capacity. Axial strain was measured and controlled from an axial gage length extensometer mounted on ridges of the test specimen. A nominal total axial strain amplitude of \pm 0.30 pct (strain range of $0.6 \mathrm{pct}$ ) was employed for all the tests. No corrections were applied for the small tapered sections of the lengths between the ridges. The specimens were inductively heated. Uniform heating of the specimen gage length was accomplished with the help of three separately adjustable sections of the induction coil and by carefully monitoring and controlling the specimen temperature using six thermocouples spot welded at equal intervals on the gage section. The temperature profile remained within $\pm 2{ }^{\circ} \mathrm{C}$ of the nominal temperature throughout each test. Metallography revealed that no cracks were initiated adjacent to the spot-welded regions during LCF testing. Stress-strain hysteresis loops were recorded continuously with an $\mathrm{X}-\mathrm{Y}$ recorder to determine the cycledependent changes in serrated flow behavior, stress, and plastic strain ranges. The stress-strain values have also been stored and processed with a PDP 11 computer.

The influence of nominal strain rate $\left(\dot{\varepsilon}=4 \times 10^{-6}\right.$ to 4 $\times 10^{-3} \mathrm{~s}^{-1}$ ) on LCF behavior was studied at $850^{\circ} \mathrm{C}$. The effects of temperature were assessed in the range $750^{\circ} \mathrm{C}$ to $950{ }^{\circ} \mathrm{C}$ at a constant strain rate of $4 \times 10^{-5} \mathrm{~s}^{-1}$. Fractographic analysis has been carried out on the failed samples by optical microscopy and scanning electron microscopy (SEM) to determine the crack initiation and propagation modes. Studies were also conducted on longitudinal sections of failed specimens to document the behavior of surface cracks and microstructural changes that occurred during LCF testing. These studies were supplemented by transmission electron microscopy (TEM) investigations for which samples were obtained $1 \mathrm{~mm}$ below the fracture surfaces normal to the loading axis. Thin foils were prepared by initially grinding the samples down to $250-\mu \mathrm{m}$ thick- ness, followed by electropolishing in a solution containing $20 \mathrm{vol}$ pct $\mathrm{H}_{2} \mathrm{SO}_{4}$ and 80 pct methanol, at $25 \mathrm{~V}$ and at a temperature of $\approx 0{ }^{\circ} \mathrm{C}$, in a twin jet apparatus.

\section{RESULTS}

\section{A. Effects of Strain Rate and Temperature on LCF Life}

A summary of the experimental results showing the influence of strain rate $(\dot{\varepsilon})$ and temperature on LCF properties, such as the number of cycles to macrocrack initiation $\left(N_{i}\right)$, the number of cycles to failure $\left(N_{f}\right)$, the peak tensile stress amplitude in the first quarter cycle $\left(\sigma_{T}\right)_{1 / 4}$, and the stress amplitude $\left(\sigma_{T}\right)_{\mathrm{Ni} / 2}$ for the cycle corresponding to half of the macrocrack initiation life, is presented in Table I. The crack initiation and propagation lives were derived by means of a quotient-curve method. In this method, as a first step, the absolute values of the peak tensile $\left(\sigma_{T}\right)$ and compressive $\left(\sigma_{c}\right)$ stresses in each cycle were plotted against the number of cycles. The quotient curve was obtained by plotting 100 $\times\left|\sigma_{C} / \sigma_{\lambda}\right|$ as an ordinate. The quotient curve initially showed a plateau region over a large number of cycles and then displayed an upward trend. For all those points in the plateau region of the quotient curve, a straight-line fit was obtained by linear regression analysis. The number of cycles corresponding to the intersection point of a parallel line drawn at a value of 3 pct higher than the regression line and the quotient curve has been taken as the macrocrack initiation life. The number of cycles corresponding to the intersection point of the quotient curve and another parallel line at 50 pct higher than the regression line has been designated as the failure life. This procedure was repeated for all the tests.

The quotient-curve method enabled the clear distinction between the changes arising in cyclic stress response due to deformation and crack initiation. For a given set of experimental conditions, the tests conducted on identical specimens showed a large variation in number of cycles to near end-of-life. On the other hand, the experimental scatter in 

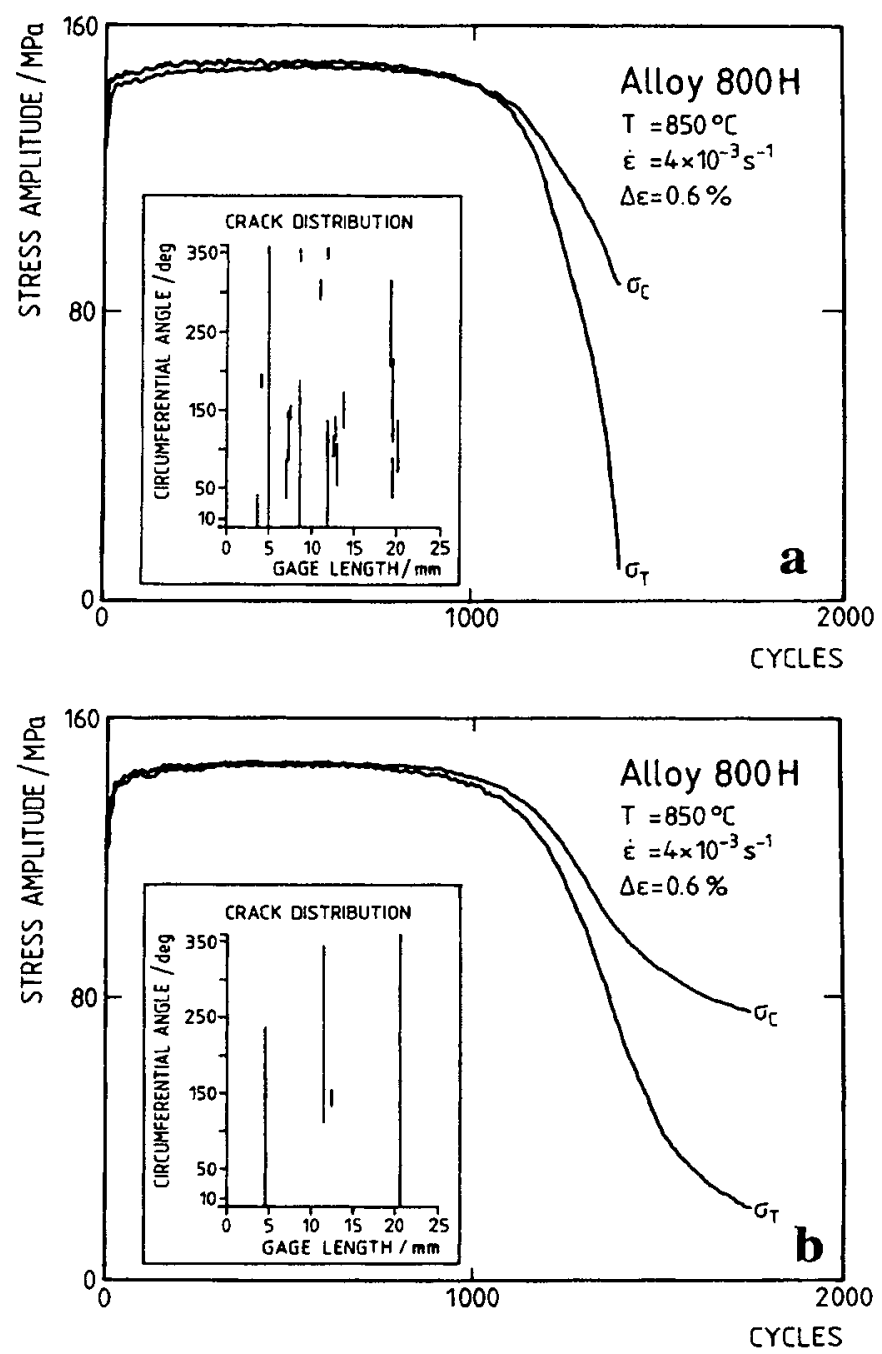

Fig. 2-(a) and $(b)$ Diagrams describing compressive $\left(\sigma_{c}\right)$ and tensile $\left(\sigma_{r}\right)$ stress response and the extension and location of macrocracks across the gage length (insert). The sample in (a) which developed a large number of microcracks exhibited a smaller number of cycles to failure.

$N_{i}$ values is comparatively small. The major factor responsible for the large scatter in end-of-life has been analyzed. Figure 2 illustrates the tensile $\left(\sigma_{T}\right)$ and compressive $\left(\sigma_{C}\right)$ stress response of two samples tested at $\dot{\varepsilon}=4 \times 10^{-3} \mathrm{~s}^{-1}$, at $850{ }^{\circ} \mathrm{C}$. The vertical lines in the inserts of Figures 2(a) and (b) describe the extension of the microcracks along the circumference and their location across the gage length of the sample measured from a reference point from one end of gage length. The sample that developed the most cracks, which were oxidation induced, exhibited a rapid fall in cyclic tensile stress and a lower number of cycles to the endof-life than the sample that contained relatively few cracks. From this observation, it can be inferred that very large scatter in the end-of-life could result at a given test condition as a result of the variation in the density of microcracks among different samples, although utmost care has been exercised to perform the LCF tests on geometrically similar samples with an identical surface finish. Thus, it appears to be more appropriate to express the influence of temperature and strain rate with respect to number of cycles

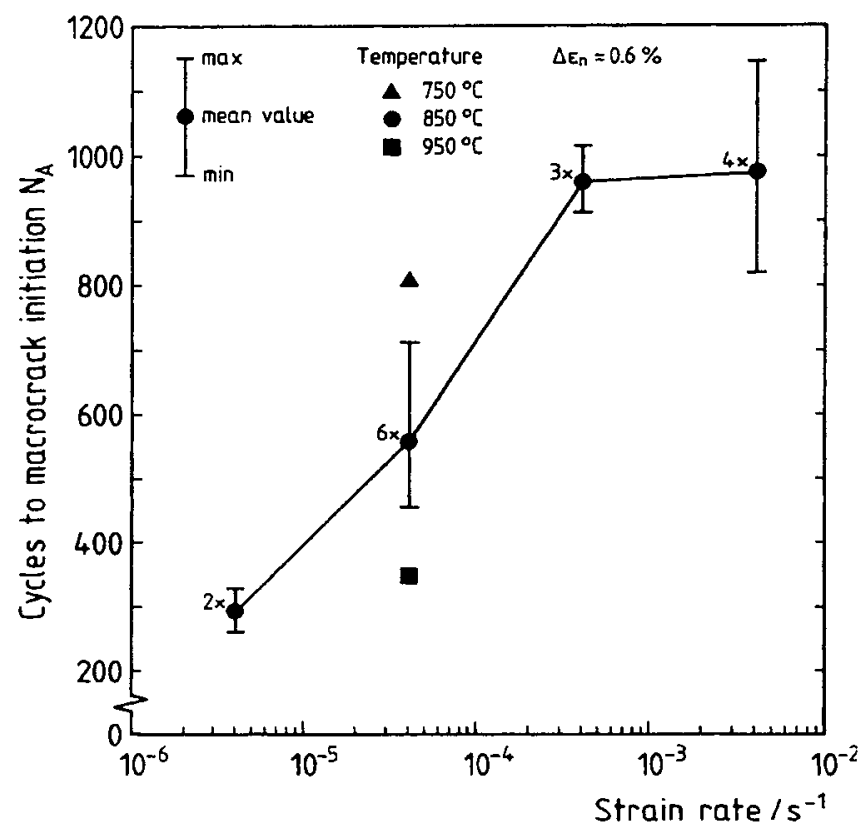

Fig. 3-Influence of temperature and strain rate on macrocrack initiation life. The numbers marked at the data points obtained at $850^{\circ} \mathrm{C}$ correspond to the number of tests conducted.

to macrocrack initiation, since the crack initiation life does not include the effects associated with growth of multiple cracks and their linkage. Therefore, in the current study, the life is expressed as number of cycles to macrocrack initiation $N_{i}$. The influence of strain rate $\left(4 \times 10^{-6}\right.$ to $4 \times$ $\left.10^{-3} \mathrm{~s}^{-1}\right)$ at $850{ }^{\circ} \mathrm{C}$ and temperature $\left(750{ }^{\circ} \mathrm{C} / 850{ }^{\circ} \mathrm{C} / 950\right.$ ${ }^{\circ} \mathrm{C}$ ) at $\dot{\varepsilon}=4 \times 10^{-5} \mathrm{~s}^{-1}$ on $N_{i}$ are shown in Figure 3 . It can be seen that, as anticipated, there is a significant reduction in LCF life as a result of increasing temperature and/or decreasing strain rate.

\section{B. Effects of Strain Rate and Temperature on Cyclic Stress Response}

The cyclic stress response curves for various strain rates at $850^{\circ} \mathrm{C}$ and different temperatures at $\dot{\varepsilon}=4 \times 10^{-5} \mathrm{~s}^{-1}$ are shown in Figures 4 and 5 , respectively. At $850^{\circ} \mathrm{C}$ and at $\dot{\varepsilon} \geq 4 \times 10^{-4} \mathrm{~s}^{-1}$, the alloy exhibited a relatively short period of cyclic hardening in the early stages of cyclic life followed by a regime of nearly stable peak stresses. Toward the end of the tests, the stress range decreased rapidly, indicating the formation of macrocracks and their subsequent growth. The degree of hardening was higher for $\dot{\varepsilon}=4 \times$ $10^{-3} \mathrm{~s}^{-1}$ than for $\dot{\varepsilon}=4 \times 10^{-4} \mathrm{~s}^{-1}$. At $950^{\circ} \mathrm{C}$ and in the tests at the two lower strain rates $\left(\leq 4 \times 10^{-5} \mathrm{~s}^{-1}\right)$ at 850 ${ }^{\circ} \mathrm{C}$, the alloy showed rapid initial softening followed by gradual softening until macroscopic crack growth occurred. At $750{ }^{\circ} \mathrm{C}$ and $\dot{\varepsilon}=4 \times 10^{-5} \mathrm{~s}^{-1}$, the alloy underwent considerable hardening prior to the onset of a continuous and pronounced softening stage. At $750{ }^{\circ} \mathrm{C}$, however, no saturation in cyclic stress response was observed such as that in the high strain rate tests at $850^{\circ} \mathrm{C}$. The higher strain rate $\left(\dot{\varepsilon} \geq 4 \times 10^{-4} \mathrm{~s}^{-1}\right)$ tests at $850{ }^{\circ} \mathrm{C}$ exhibited serrated flow in the plastic regions of stress-strain hysteresis loops (Figure 6(a)). Figure 6(b), constructed with the help of data stored in a PDP 11 computer, illustrates more precisely the 


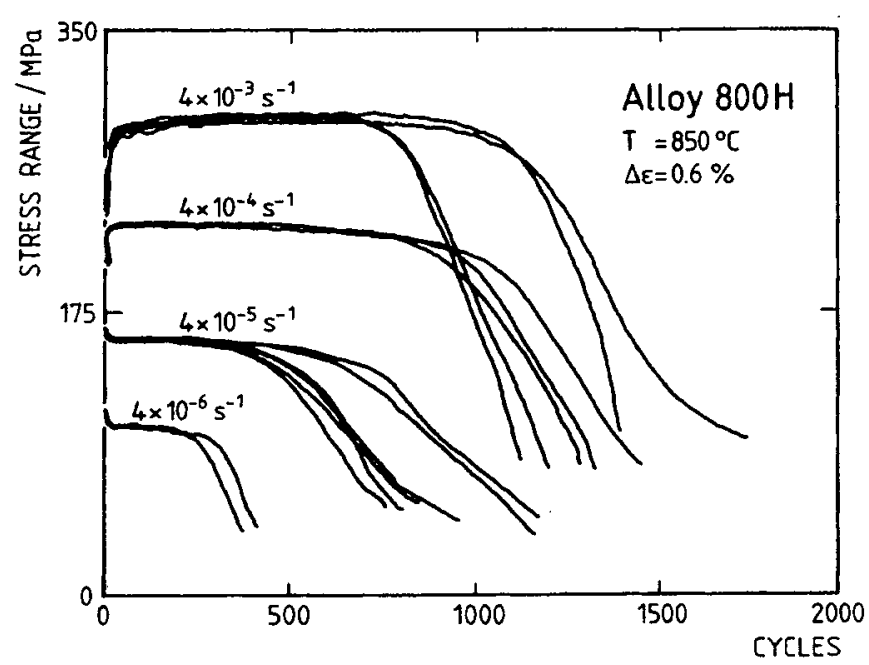

Fig. 4-Effects of strain rate on cyclic stress response at $850^{\circ} \mathrm{C}$. Each curve represents the stress response of a single specimen.

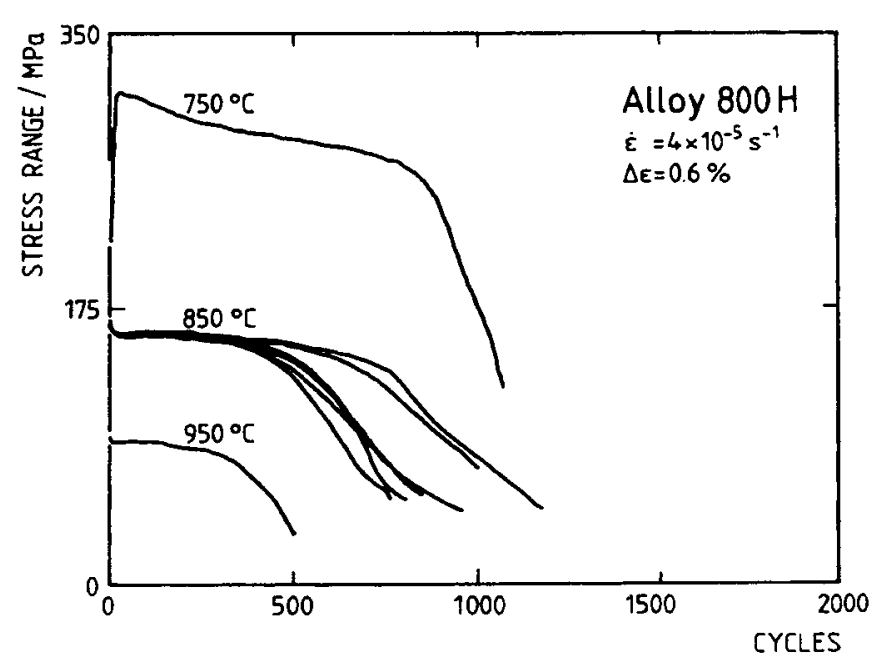

Fig. 5-Influence of temperature on cyclic stress response $\left(\dot{\varepsilon}=4 \times 10^{-5}\right.$ $\left.\mathrm{s}^{-1}\right)$.

actual serrated flow observed in the first quarter cycle of Figure 6(a). Serrated flow has disappeared after about 200 cycles (Table I). Serrated fiow is considered as one of the manifestations of DSA.

\section{Fracture Behavior}

Cracks invariably initiated at the specimen surface in all test conditions. At $850^{\circ} \mathrm{C}$, a clear transition in crack initiation and propagation behavior was found from transgranular stage-II cracking at $\dot{\varepsilon} \geq 4 \times 10^{-4} \mathrm{~s}^{-1}$ to intergranular initiation and propagation at $\dot{\varepsilon} \leq 4 \times 10^{-5} \mathrm{~s}^{-1}$ (Figures 7 (a) and (b)). Transgranular stage-II cracking was characterized by its occurrence along the planes which were oriented $\approx 90$ deg to the applied stress axis. The test at $950{ }^{\circ} \mathrm{C}$ also showed intergranular crack initiation and propagation (Figure $7(\mathrm{c})$ ). At $750^{\circ} \mathrm{C}$, at $\dot{\varepsilon}=4 \times 10^{-5} \mathrm{~s}^{-1}$, crack propagation was characterized by mixed transgranular plus brittle intergranular mode of cracking, despite the fact that the initia-

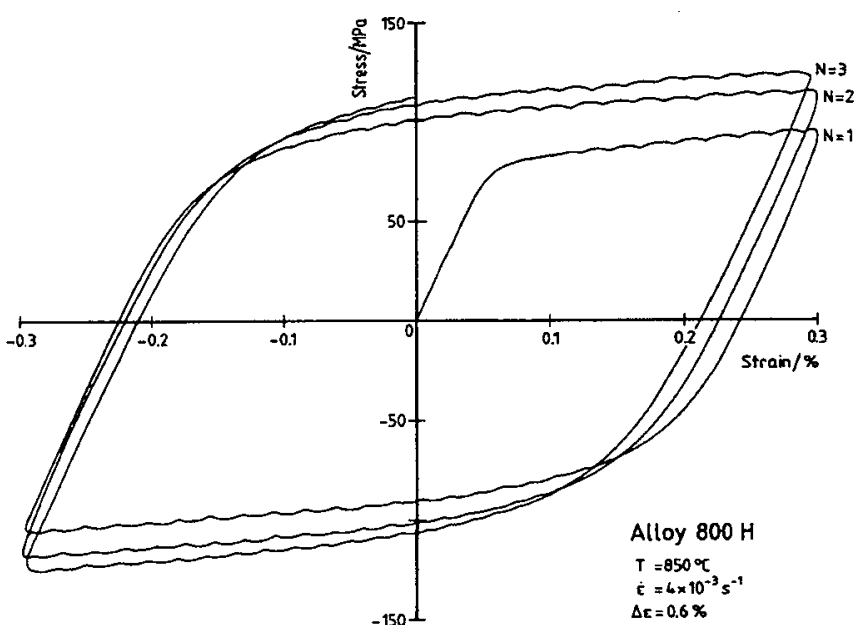

(a)

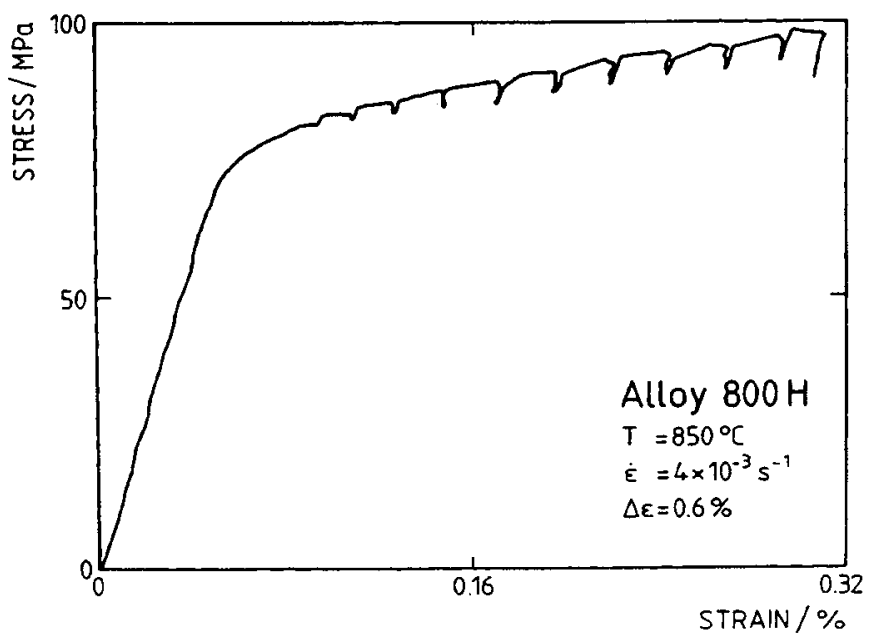

(b)

Fig. 6-(a) Stress-strain hysteresis loops showing serrated flow in the plastic regions at $850^{\circ} \mathrm{C}$ at a strain rate of $4 \times 10^{-3} \mathrm{~s}^{-1}$ and $(b)$ magnified view of the first quarter cycle of stress-strain hysteresis loop shown in (a).

tion and early propagation took place by stage-II transgranular mechanism (Figure $7(\mathrm{~d})$ ).

\section{Deformation-Induced Substructure}

The deformation behavior is described in terms of slip character, which is considered as a measure of the degree to which dislocations tend to disperse during plastic deformation..$^{[4]}$ In general, wavy slip occurred at $950^{\circ} \mathrm{C}$ and over the wide range of strain rates investigated at $850^{\circ} \mathrm{C}$. The specimens deformed at $850^{\circ} \mathrm{C}$ and $\dot{\varepsilon} \geq 4 \times 10^{-4} \mathrm{~s}^{-1}$ revealed cell formation (the walls of which were made up of disordered arrays of dislocations) with randomly distributed dislocations in cell interiors (Figure 8(a)). Instead, at 950 ${ }^{\circ} \mathrm{C}$ and in the lower strain rate tests at $850{ }^{\circ} \mathrm{C}$, subgrains (with walls made up of ordered arrays of dislocations) were frequently observed (Figure $8(\mathrm{~b})$ ). At $750^{\circ} \mathrm{C}$ and $\dot{\varepsilon}=4 \times$ $10^{-5} \mathrm{~s}^{-1}$, the deformation substructure was composed of planar slip bands (Figure 8(c)) and cells. There was no evidence of planar slip in the tests at $850^{\circ} \mathrm{C}$ and $950^{\circ} \mathrm{C}$ and slip was entirely homogeneous. 


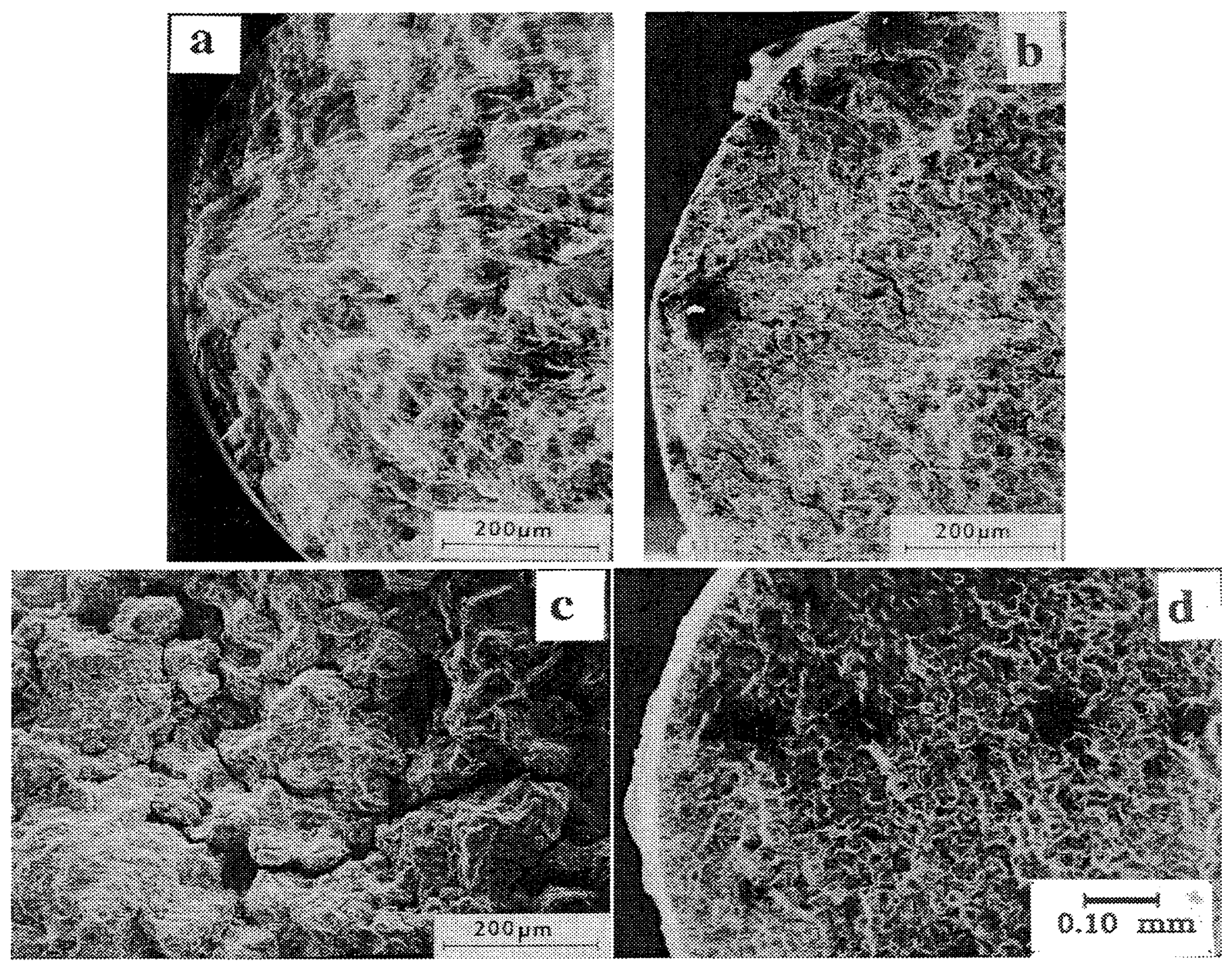

Fig. 7-(a) Fracture surface illustrating stage-II transgranular crack initiation at $850^{\circ} \mathrm{C}, \dot{\varepsilon}=4 \times 10^{-3} \mathrm{~s}^{-1}$; (b) intergranular crack initiation and propagation at $850^{\circ} \mathrm{C}, \dot{\varepsilon}=4 \times 10^{-6} \mathrm{~s}^{-1} ;(\mathrm{c})$ intergranular fracture at $950^{\circ} \mathrm{C}$ showing a large number of secondary cracks; and (d) brittle intergranular plus transgranular mode of propagation at $750^{\circ} \mathrm{C}$.

\section{E. Evolution of Microstructure during LCF Deformation}

In the solution-annealed and quenched condition, the alloy contained relatively coarse and randomly distributed polyhedral precipitates in both intra- and intergranular regions. These have been identified as primary $\operatorname{Ti}(C, N)$ by energy dispersive $\mathrm{X}$-ray analysis (EDXA). These primary carbides did not show any rational orientation relationship with respect to the matrix. These were nucleated in the melt and were not dissolved during the solutionizing treatment. The shape, size, and distribution of the $\operatorname{Ti}(C, N)$ did not undergo any conspicuous change during cyclic deformation at any of the test conditions employed.

Although the starting material was free from precipitates other than primary $\mathrm{Ti}(\mathrm{C}, \mathrm{N})$, fatigue-tested material exhibited a variety of phases such as chromium-rich $\mathrm{M}_{23} \mathrm{C}_{6}, \mathrm{TiC}$, $\sigma, G$ phase, and parallel plates of $\mathrm{M}_{23} \mathrm{C}_{6}$. The $\sigma$ and $G$ phases have been reported to have stoichiometries of $\mathrm{FeCr}$ and $\mathrm{Ti}_{6} \mathrm{Ni}_{16} \mathrm{Si}_{7}$, respectively. ${ }^{(5)}$ Their location, size, shape, and distribution strongly depended on both temperature and $\dot{\varepsilon}$. The regions surrounding the primary carbides acted preferably as the primary sites for carbide precipitation.

At all the test conditions, the intergranular precipitates were generally rather coarse compared to intragranular precipitates. The precipitation of $\mathrm{M}_{23} \mathrm{C}_{6}$ was particularly pronounced at $750{ }^{\circ} \mathrm{C}$. Bright- and dark-field TEM micrographs of the substructure at $750{ }^{\circ} \mathrm{C}$ revealed preferential association of $\mathrm{M}_{23} \mathrm{C}_{6}$ precipitates (Figure 9(a) and (b)) with dislocations and dislocation tangles in the intragranular regions. The grain boundaries contained discrete particles of $\mathrm{M}_{23} \mathrm{C}_{6}$, as shown in Figures 10 (a) and (b). Cyclic deformation at $850^{\circ} \mathrm{C}$ and $\dot{\varepsilon} \geq 4 \times 10^{-4} \mathrm{~s}^{-1}$ caused precipitation of large amounts of very fine cube-shaped $\mathrm{M}_{23} \mathrm{C}_{6}$ in the matrix that served as pinning points for dislocations (Figure 11(a) and (b)). Occasionally, secondary TiC was also found in the matrix. Apart from these discrete carbides, marked precipitation of $\mathrm{M}_{23} \mathrm{C}_{6}$ particles in the form of par- 


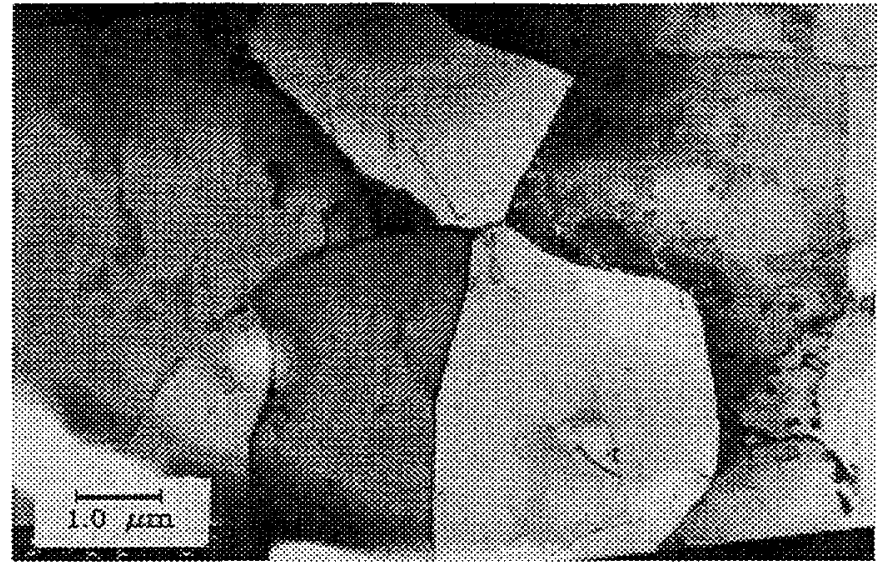

(a)

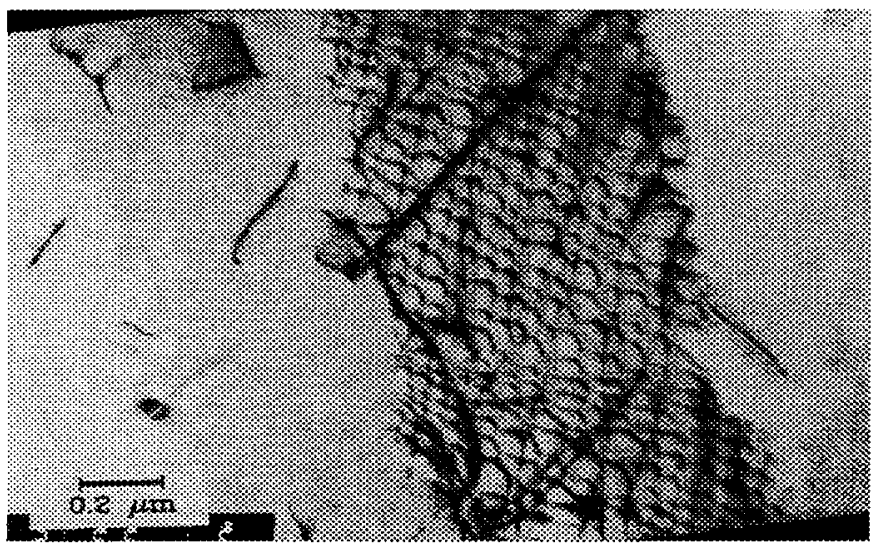

(b)

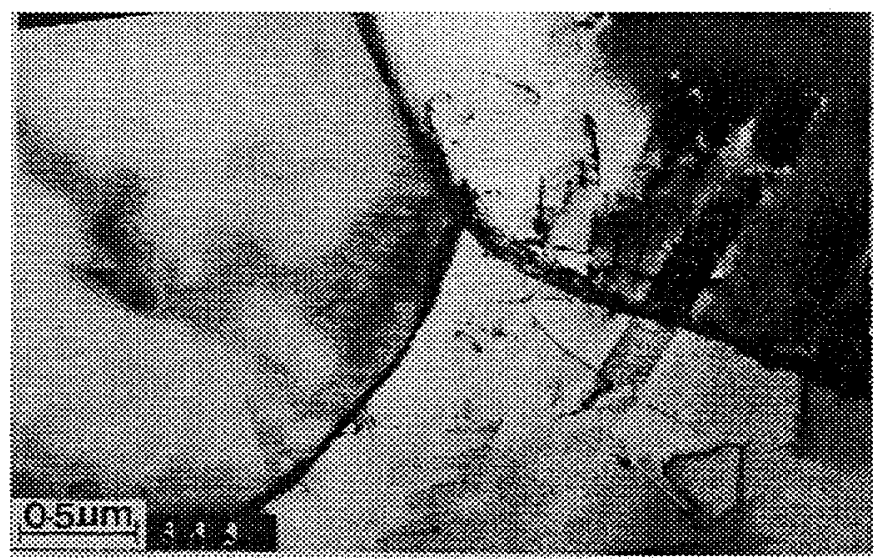

(c)

Fig. 8-(a) Cell structure in samples deformed at $850{ }^{\circ} \mathrm{C}$ with a strain rate of $4 \times 10^{-3} \mathrm{~s}^{-1}$; (b) subgrain wall containing orderly arranged dislocations at $850^{\circ} \mathrm{C}, \dot{\varepsilon}=4 \times 10^{-5} \mathrm{~s}^{-1}$; and (c) mixed mode deformation containing cells and planar slip bands at $750^{\circ} \mathrm{C}$.

allel plates occurred at grain boundaries and also at incoherent ledges of twin boundaries. This type of precipitation of $\mathrm{M}_{23} \mathrm{C}_{6}$ has also occurred at $750{ }^{\circ} \mathrm{C}$. Details of the microstructure containing parallel plates of $\mathrm{M}_{23} \mathrm{C}_{6}$ are illustrated in Figures 12(a) through (c). Also at $850^{\circ} \mathrm{C}$ and $\dot{\varepsilon} \leq$ $4 \times 10^{-5} \mathrm{~s}^{-1}$, copious amounts of secondary TiC precipi-

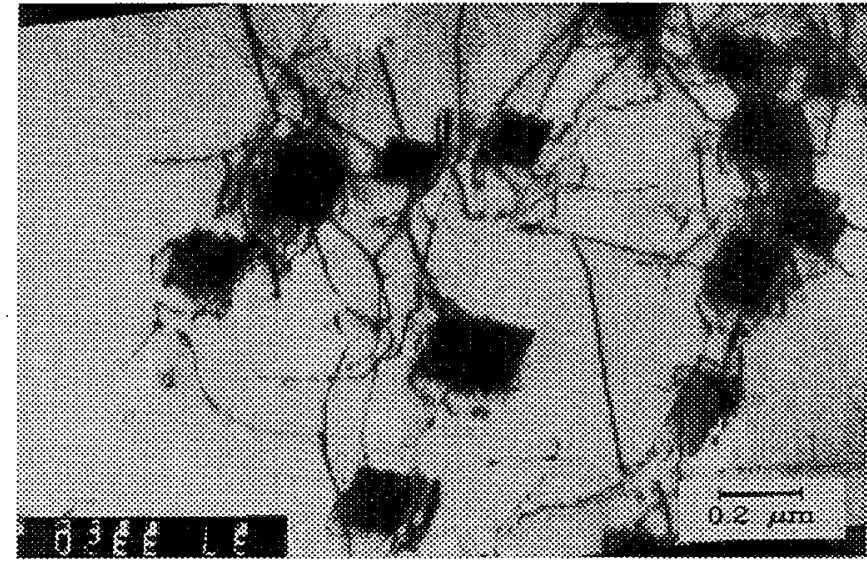

(a)

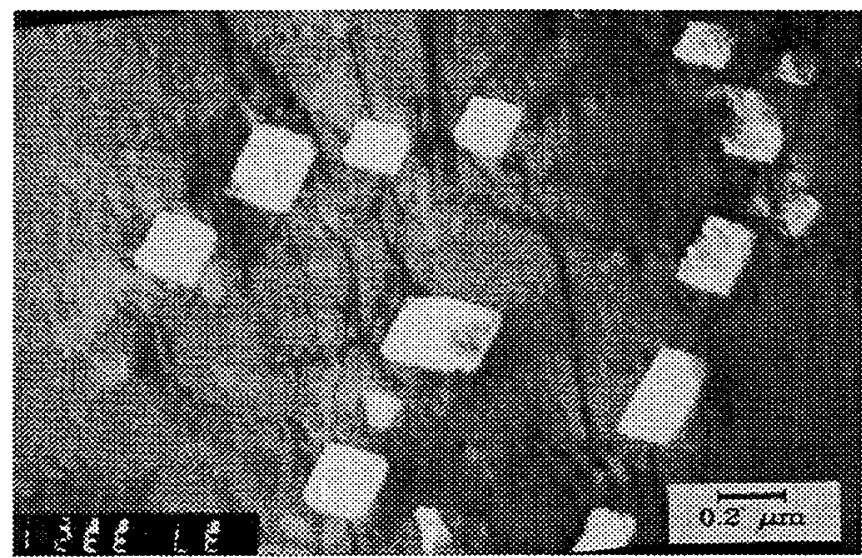

(b)

Fig. 9-(a) Bright- and (b) dark-field TEM micrographs showing intragranular $\mathrm{M}_{23} \mathrm{C}_{6}$ associated with dislocations and dislocation tangles at $750^{\circ} \mathrm{C}$.

tated and, together with $\mathrm{M}_{23} \mathrm{C}_{6}$, were found in both intraand intergranular regions (Figure 13(a)). In the matrix, TiC generally precipitated on the dislocations that have been coagulated. ${ }^{[5]}$ Decreasing the strain rate leads to the coarsening of intragranular $\mathrm{M}_{23} \mathrm{C}_{6}$ and the formation of a continuous layer of $\mathrm{M}_{23} \mathrm{C}_{6}$ on some of the grain boundaries (Figure 13(b)); it also causes the occurrence of $\sigma$ phase $(\mathrm{FeCr})$ and $G$ phase in minor amounts. At $950^{\circ} \mathrm{C}$, TiC was the predominant phase which coexisted with $\mathrm{M}_{23} \mathrm{C}_{6}$ both in the intra- and intergranular regions. In general, the total volume fraction of intragranular precipitates significantly decreased and their-size increased at higher temperatures and lower $\dot{\varepsilon}$.

\section{DISCUSSION}

\section{A. Cyclic-Deformation-Induced Precipitation}

The precipitation behavior of alloy $800 \mathrm{H}$ under stressfree thermal exposure conditions has been investigated in detail. ${ }^{[5]}$ It was noticed that TiC occurs readily at temperatures higher than $900{ }^{\circ} \mathrm{C}$, whereas $\mathrm{M}_{23} \mathrm{C}_{6}$ forms preferentially at temperatures lower than $800^{\circ} \mathrm{C}$. At about $850^{\circ} \mathrm{C}$, the precipitation kinetics of $\mathrm{M}_{23} \mathrm{C}_{6}$ and $\mathrm{TiC}$ were reported 


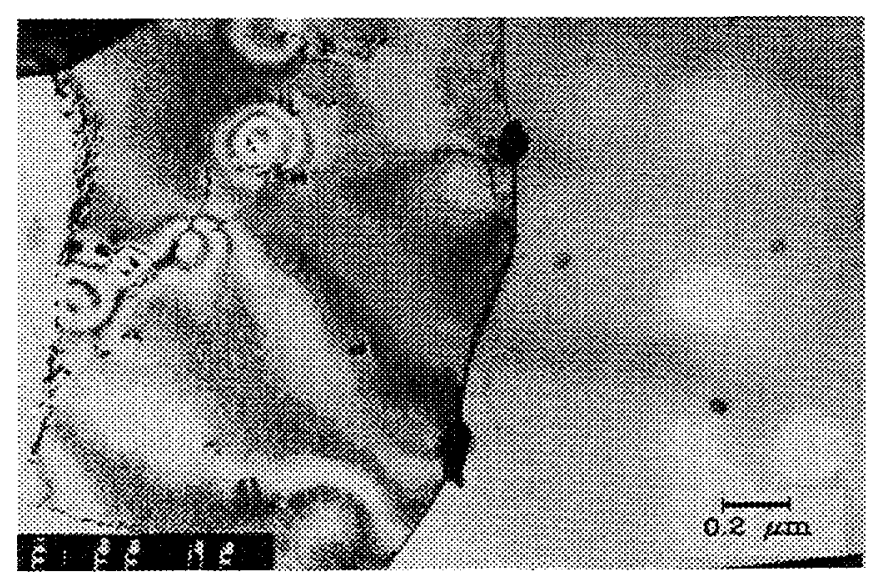

(a)

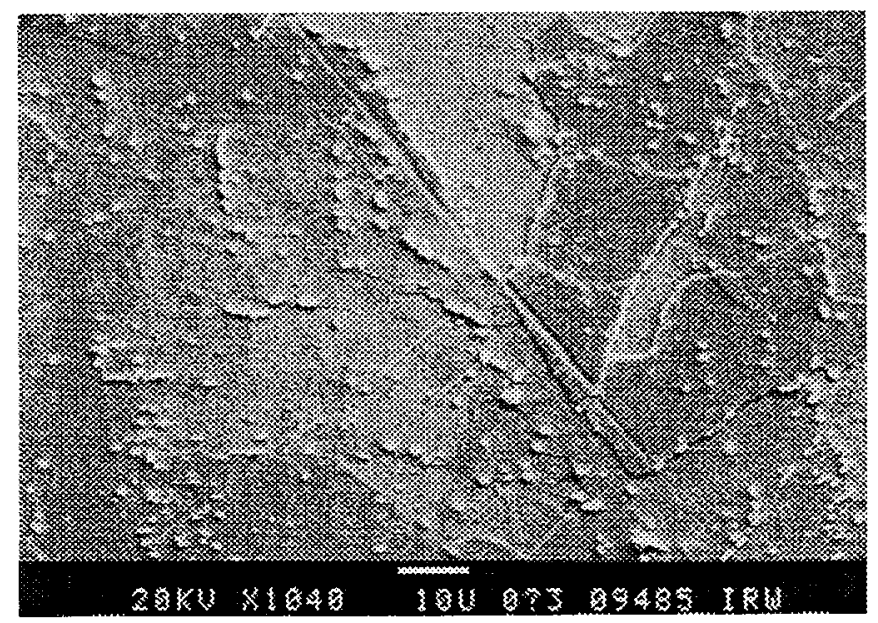

(b)

Fig. 10-(a) Bright-field TEM micrograph depicting intra- and intergranular $\mathrm{M}_{23} \mathrm{C}_{6}$; and (b) SEM photograph showing the intra- and intergranular $\mathrm{M}_{23} \mathrm{C}_{6}$ at $750^{\circ} \mathrm{C}$.

to be similar, ${ }^{[s]}$ and as observed in this investigation, both phases coexist under stress-free thermal exposure at $850^{\circ} \mathrm{C}$. The time-temperature-transformation diagram of Degischer Aigner ${ }^{[6]}$ predicts an incubation period of $\approx 6$ hours for the occurrence of $\mathrm{TiC}$ under stress-free thermal exposure at 850 ${ }^{\circ} \mathrm{C}$ for alloy 800 . Since the carbon content in alloy $800 \mathrm{H}$ is higher than that in alloy 800 , it can be expected that the incubation period for $\mathrm{TiC}$ precipitation would be reduced. In this study, TiC precipitated in LCF tests $\left(\dot{\varepsilon}=4 \times 10^{-3}\right.$ $\mathrm{s}^{-1}$ at $850^{\circ} \mathrm{C}$ ) that lasted for only 1 hour. In general, LCF deformation enables the nucleation and growth of carbides to proceed quickly because of the generation of nucleation sites such as dislocations and dislocation tangles and enhanced diffusion of solute elements that make up the carbides with aid of nonequilibrium vacancies generated during deformation. Cyclic straining creates vacancies at a rate greater than unidirectional deformation or stress-free exposure at elevated temperatures. ${ }^{[7.81}$ It has been speculated that cyclic deformation generates vacancies by nonconservative jog motion or by annihilation of nonscrew dislocations in the matrix. ${ }^{[7.8]}$

At higher strain rates at $850^{\circ} \mathrm{C}$ and $750^{\circ} \mathrm{C}$, the parallel
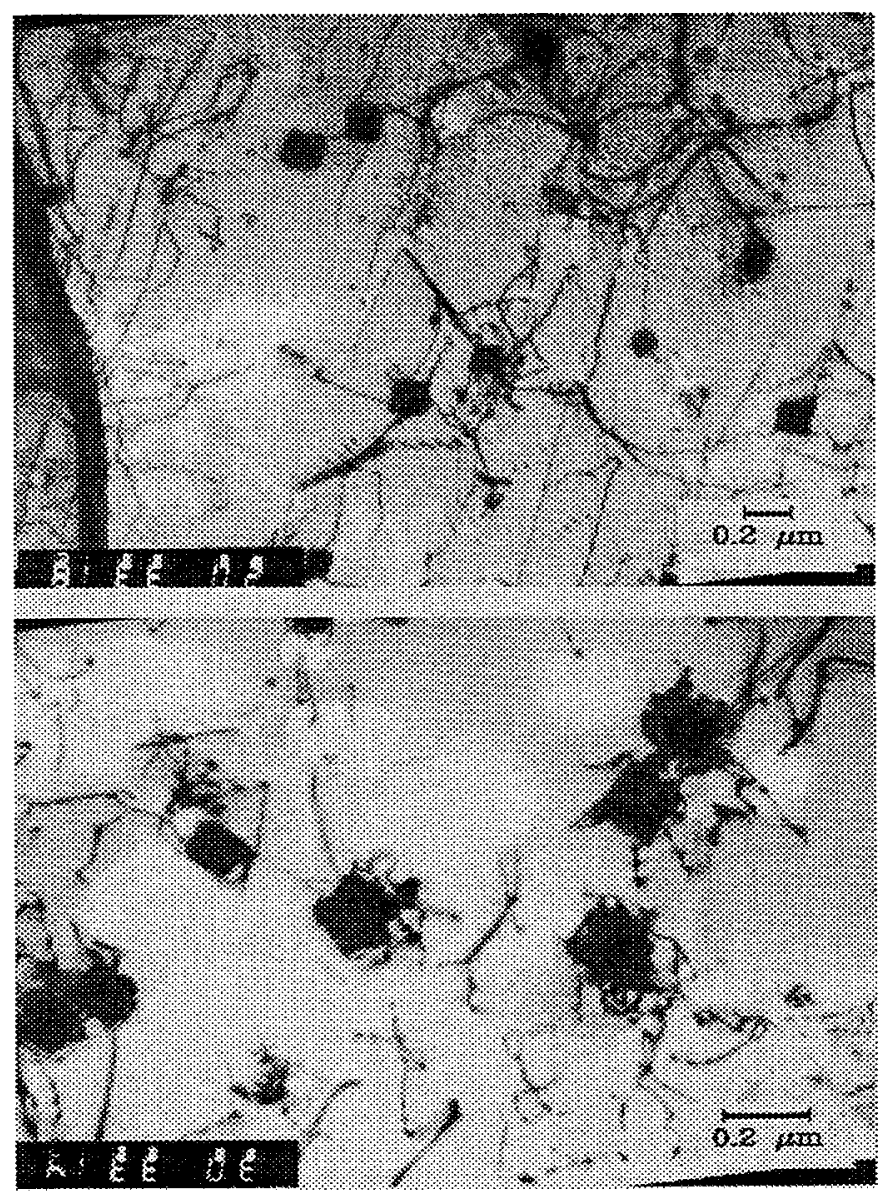

Fig. 11-Bright-field TEM micrograph illustrating dislocation-precipitate interactions at $850^{\circ} \mathrm{C}, \dot{\varepsilon}=4 \times 10^{-3} \mathrm{~s}^{-1}$. The fine cube-shaped precipitates are $\mathrm{M}_{23} \mathrm{C}_{6}$.

plates of $\mathrm{M}_{23} \mathrm{C}_{6}$ have grown on randomly oriented grain boundaries such that there is no association between particle orientation and applied stress direction (Figure 12). This type of precipitation exhibited a stronger preference to form on those grain and incoherent ledges of twin boundaries that are beneath the fracture surface (Figure 12(c)) and in the areas surrounding the microcracks that are away from the fracture zone. The platelets advanced into the grain in a direction perpendicular to the grain boundary and incoherent ledges of the twin. The majority of the carbide plates have a $\langle 100\rangle_{\gamma} / /\langle 100\rangle_{\mathrm{M}_{23} \mathrm{C}_{6}}$ orientation relationship with the matrix. Small boundary precipitates, presumably formed prior to the nucleation of parallel plates, were found along the grain boundaries and incoherent ledges of twin. Precipitation of parallel platelets occurred profusively in the high strain rate $\left(\dot{\varepsilon}=4 \times 10^{-3} \mathrm{~s}^{-1}\right)$ LCF tests that promoted cyclic hardening. Precipitation of $\mathrm{M}_{23} \mathrm{C}_{6}$ platelets has been reported in isothermally aged as well as creep-tested samples of alloy $800 \mathrm{H} .{ }^{[9]}$ The mechanism by which the parallel platelets occur at the incoherent ledges of twins during isothermal exposure of austenitic stainless steels has been outlined by Singhal and Martin. ${ }^{[10]}$ They found that Shockley partial dislocations are emitted from the boundary during the growth of boundary precipitates and subsequently generated over the stacking fault. It has been suggested that 


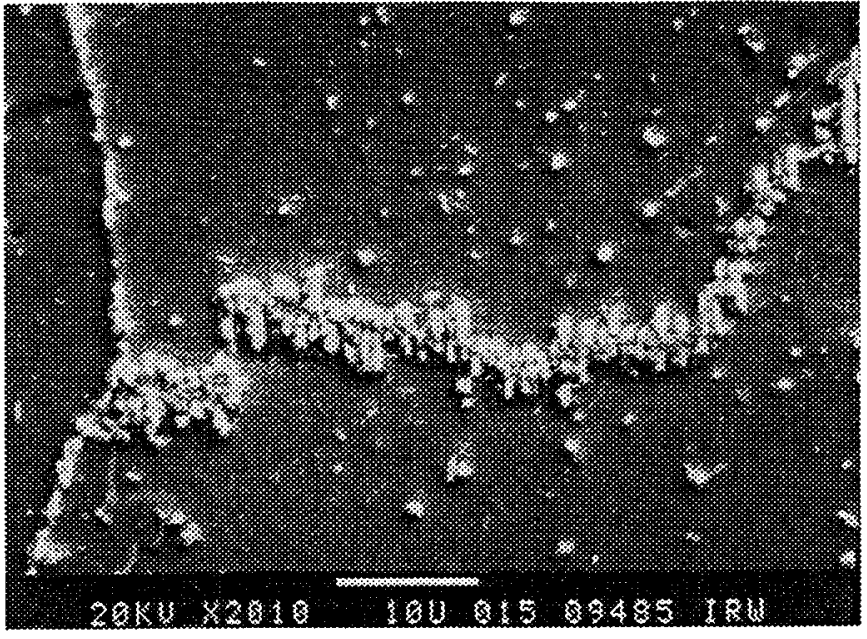

(a)

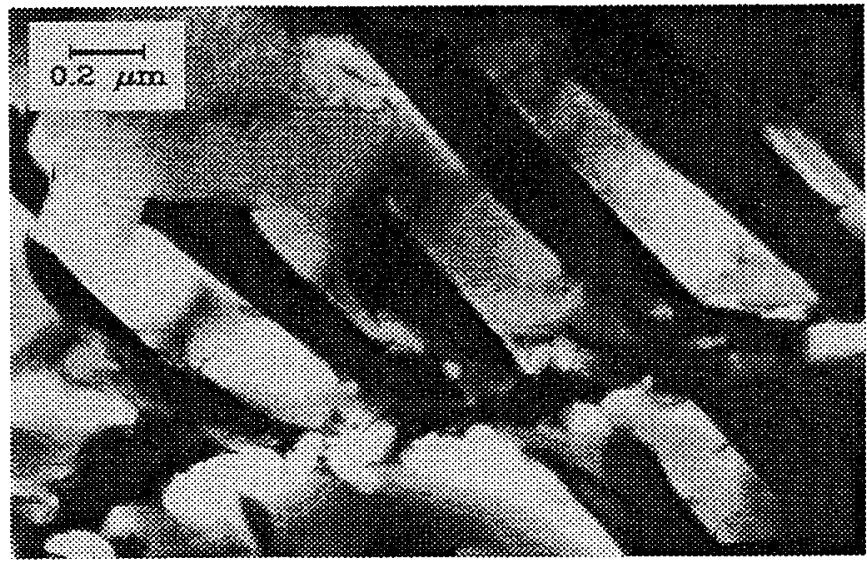

(b)

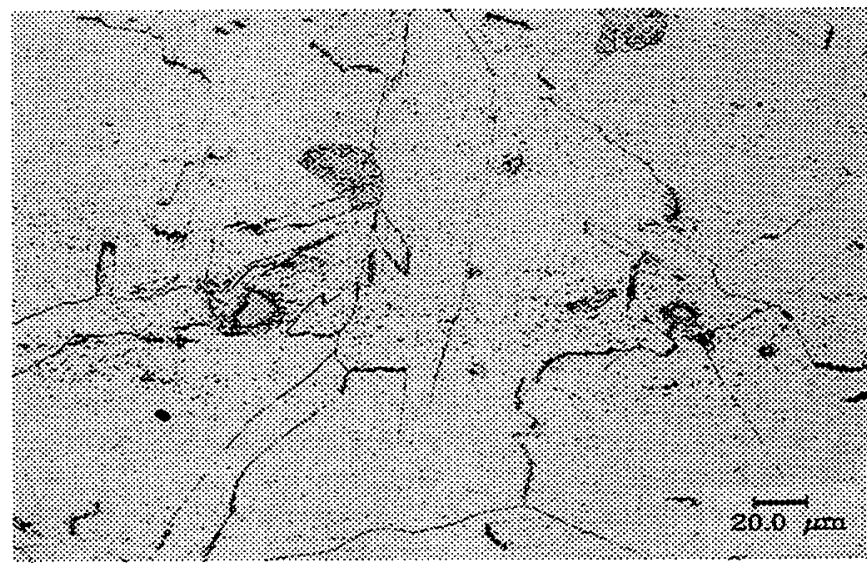

(c)

Fig. 12-(a) SEM photograph showing massive precipitation of $\mathrm{M}_{23} \mathrm{C}_{6}$ on a grain boundary that has been migrated; $(b)$ bright-field TEM micrograph showing the nucleation of massive precipitates of $\mathrm{M}_{23} \mathrm{C}_{6}$ on grain boundaries; and (c) optical micrograph showing precipitation of parallel plates of $\mathrm{M}_{23} \mathrm{C}_{6}$ on grain and incoherent twin boundaries in the area just below the fracture surface.

the new precipitates nucleate on the partial dislocations and grow over stacking fault, producing the characteristic plate

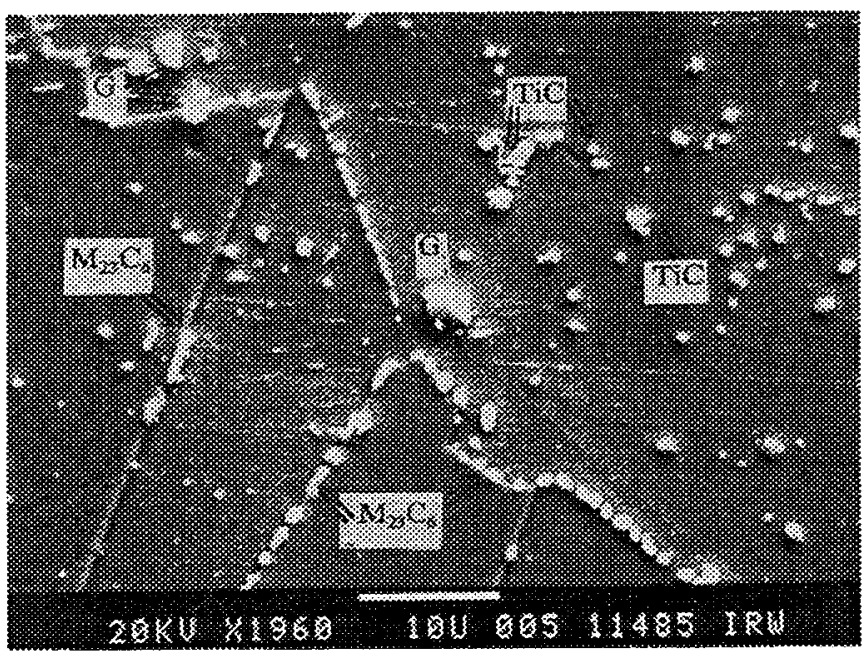

(a)

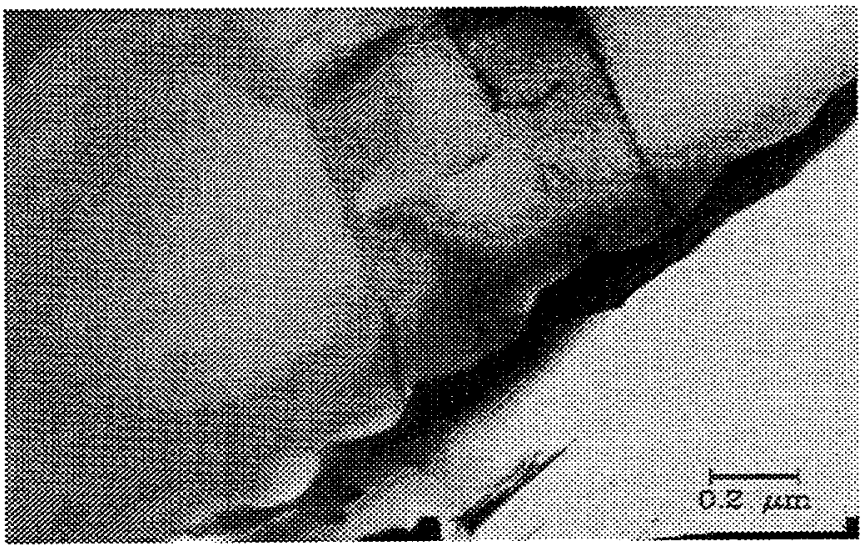

(b)

Fig. 13-(a) SEM photograph illustrating the distribution of $\mathrm{TiC}, \mathrm{M}_{23} \mathrm{C}_{6}$, and $G$ phase in the tests conducted at $850^{\circ} \mathrm{C}, \dot{\varepsilon}=4 \times 10^{-6} \mathrm{~s}^{-1}$; and $(b)$ bright-field TEM micrograph showing the continuous film of $\mathrm{M}_{23} \mathrm{C}_{6}$ on grain boundary, $\dot{\varepsilon}=4 \times 10^{-5} \mathrm{~s}^{-1}$.

shape. The mechanism of nucleation of massive precipitates during cyclic deformation appears to be consistent with that advanced by Singhal and Martin for isothermal exposure of stainless steels. The major driving force for massive precipitation appears to be carbon supersaturation; an increase in the carbon content should favor this type of precipitation. ${ }^{[11]}$ Solution annealing at $1175^{\circ} \mathrm{C}$ dissolves most of the carbides which, on subsequent exposure to test temperature, reprecipitate heterogeneously on the grain and the incoherent ledges of twin boundaries and increase the chance of massive precipitation. The long-term stability of these precipitates is particularly important, since the transformation of such a large structure to a brittle intermetallic phase such as sigma could lead to a detrimental effect on LCF life.

\section{B. Correlation between Cyclic Stress Response, Deformation, and Precipitation Behavior}

The cyclic stress response at $750^{\circ} \mathrm{C}$ was characterized by rapid hardening to a maximum stress followed by rapid softening (Figure 5). Similar stress response was observed 


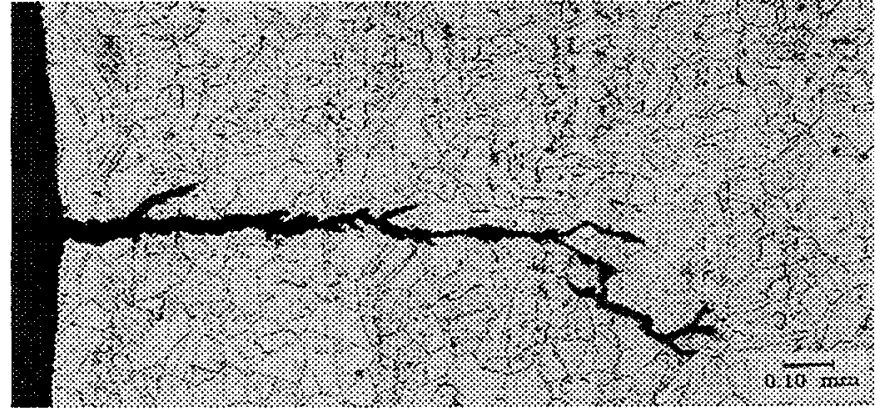

Fig. 14-Optical micrograph of the longitudinal section illustrating transgranular microcrack initiation and propagation at $850^{\circ} \mathrm{C}, \dot{\varepsilon}=4 \times$ $10^{-4} \mathrm{~s}^{-1}$. It can be noticed that the crack flanks contain a very thin oxide layer and that the crack shows a tendency for branching.

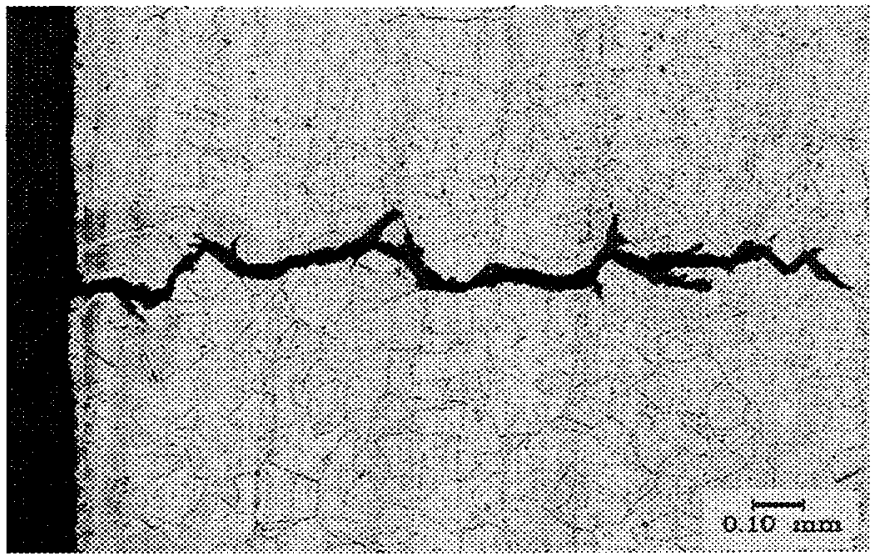

Fig. 15 -Intergranular crack initiation and propagation at $850^{\circ} \mathrm{C}, \dot{\varepsilon}=4$ $\times 10^{-5} \mathrm{~s}^{-1}$.

in several alloy systems. These include nickel-base alloys strengthened by $\gamma^{\prime}$ and $\gamma^{\prime \prime},{ }^{[12-18]} \mathrm{Al}-\mathrm{Cu}^{[19]}$ hardened by $\theta$, and ordered intermetallics $\mathrm{Ni}_{3} \mathrm{Mn}^{[20]}$ and $\mathrm{Cu}_{3} \mathrm{Au} .{ }^{[2]}$ The initial hardening at $750{ }^{\circ} \mathrm{C}$ can be associated with the combined effects of accumulation of dislocations in planar slip bands (Figure 8(c)) and interaction between dislocations and $\mathrm{M}_{23} \mathrm{C}_{6}$ in the intragranular regions. The evolution of substructure at $750{ }^{\circ} \mathrm{C}$ gives interesting indications about the origins of cyclic softening. The preferential movement of dislocations in planar slip bands leads to the formation of pileups at the intersections of grain boundaries and slip bands. The cumulative effect of stress concentrations arising out of such pileups could develop intergranular cracks. The presence of a large number of brittle intergranular cracks in the bulk reduces the load-bearing area in the LCF specimen, and this leads to smaller cyclic tensile stresses.

At $850^{\circ} \mathrm{C}$ and $\dot{\varepsilon} \leq 4 \times 10^{-5} \mathrm{~s}^{-1}$ and at $950{ }^{\circ} \mathrm{C}$ and $\dot{\varepsilon}=$ $4 \times 10^{-5} \mathrm{~s}^{-1}$, the alloy displayed rapid softening in the initial stages followed by very gradual softening. Annihilation of dislocations at the grain boundaries and dynamic recovery by thermally activated climb gain importance at the higher temperatures and lower strain rates. The occurrence of the latter phenomenon is reflected by the development of subgrains with sharp walls. The transition to more gradual softening after a few cycles appears to coincide with the commencement of carbide precipitation in the grain interiors. Carbide strengthening counterbalances the softening effects associated with the annihilation and rearrangement of dislocations. ${ }^{[22]}$

At $850^{\circ} \mathrm{C}$ and $\dot{\varepsilon} \geq 4 \times 10^{-4} \mathrm{~s}^{-1}$, the alloy showed initial hardening followed by a prolonged saturation stage (Figure 4). Under these testing conditions, the serrated flow was present in the plastic portions of stress-strain hysteresis loops (Figure 6), indicating that DSA may be additionally responsible for initial hardening. Serrated yielding has been reported earlier during cyclic deformation of alloy 800 at temperatures between $538{ }^{\circ} \mathrm{C}$ and $650{ }^{\circ} \mathrm{C}^{[23.24]}$ and in the monotonic tensile tests between $400^{\circ} \mathrm{C}$ and $850^{\circ} \mathrm{C} .{ }^{[25]} \mathrm{Dy}-$ namic strain aging has been considered to result from the solute drag exerted on mobile dislocations by carbon atoms. Evidence of solute drag during cyclic deformation in alloy $800 \mathrm{H}$ has been reported by Villagrana et al. ${ }^{[24]} \mathrm{An}$ alternative mechanism of DSA has been proposed by Mulford and Kocks, ${ }^{[26]}$ which is referred to as the dislocation-dislocation interaction model. This model suggests that the mobile dislocations are temporarily arrested at forest dislocations. Solute atmospheres form on the forest dislocation and then drain by pipe diffusion from the forest dislocations to the mobile dislocations during the waiting time. The extreme cyclic hardening observed in high strain-rate tests at $850^{\circ} \mathrm{C}$ and the observed pinning of dislocations by carbides in the current study indicate that both carbide precipitation and solute drag could contribute to the development of serrated flow at elevated temperatures.

\section{Time-Dependent Processes Influencing Fatigue Life}

At $850^{\circ} \mathrm{C}$, the decrease in fatigue life with decreasing $\dot{\varepsilon}$ (Figure 3 ) corresponds to a transition in crack initiation and propagation modes from entirely transgranular at $\dot{\varepsilon} \geq 4$ $\times 10^{-4} \mathrm{~s}^{-1}$ (Figure 14) to completely intergranular initiation and propagation at lower strain rates (Figure 15). A similar trend in crack initiation mode was seen as the temperature was raised at $\dot{\varepsilon}=4 \times 10^{-5} \mathrm{~s}^{-1}$. Microstructural analysis by TEM and the information gained through longitudinally sectioned specimens enabled the identification of the timedependent processes, which operate simultaneously with the cyclic deformation process at various conditions. These processes are (a) dynamic strain aging, (b) heavy precipitation of $\mathrm{M}_{23} \mathrm{C}_{6}$ in the form of parallel plates, (c) timedependent strain accumulation (creep deformation), and (d) oxidation. It is observed that each of these processes occupies a characteristic range of test conditions and that their dominance is altered by varying the temperature and strain rate.

In terms of its effect on cyclic life, DSA has been shown to have a detrimental effect under strain-controlled conditions. The manifestations characterizing the predominance of the DSA process are ${ }^{[27.28 .29]}$ (a) serrated flow, (b) the occurrence of planar slip, (c) a sharp increase in half-life stress with decreasing $\varepsilon$, i.e., negative strain-rate sensitivity, (d) rapid cyclic hardening, and (e) intergranular fracture. Although the intergranular fracture had occurred as a result of the decrease in strain rate at $850^{\circ} \mathrm{C}$, none of the other features that portray DSA could be sustained. The serrated flow and cyclic hardening were limited to $\dot{\varepsilon} \geq 4 \times 10^{-4}$ $\mathrm{s}^{-1}$. This indicates that DSA is effective only in the high $\varepsilon$ regime. Under the influence of DSA, the higher stresses developed during cyclic deformation could lead to a large stress concentration at the crack tip and would enhance 
crack growth rate, thus reducing life. Tests conducted in high vacuum on alloy $800 \mathrm{H}$ at $600{ }^{\circ} \mathrm{C}$ clearly reveal the shortening of crack initiation phase due to DSA. ${ }^{[30]}$ The precipitation of $\mathrm{M}_{23} \mathrm{C}_{6}$ (parallel plates) may be expected to lead to a marked reduction in high-temperature ductility, an important mechanical property on which the LCF life depends to a great extent. The life under high strain-rate conditions might have been much larger without the interference of these two time- and temperature-dependent phenomena.

The departure from the tendency to deform by planar slip at $750{ }^{\circ} \mathrm{C}$ and $\dot{\varepsilon}=4 \times 10^{-5} \mathrm{~s}^{-1}$ (Figure $8(\mathrm{c})$ ) to a more homogeneous deformation at temperatures $\geq 850{ }^{\circ} \mathrm{C}$ coincided with the initiation of surface intergranular cracks and reduction in life. Similarly, at $850^{\circ} \mathrm{C}$, there is a change in substructure from disordered cells to organized sub-boundaries as the strain rate is decreased. There is no consensus on the slip character dependence of cracking modes and fatigue life. The time-dependent deformation and concomitant change from planar slip to a more homogeneous deformation has been mentioned earlier as one of the major factors for substantial reduction in cyclic life of ASTROLOY* that has been observed in vacuum upon decreasing the strain rate from $1 \times 10^{-2}$ to $5 \times 10^{-5} \mathrm{~s}^{-1} \cdot{ }^{[31]}$ In $\mathrm{RENE}^{*}$

*ASTROLOY and RENÉ are trademarks of General Electric Company, Fairfield, CT.

95 at $649^{\circ} \mathrm{C}$, Bashir and Antolovich ${ }^{[32]}$ have also observed lower fatigue lives under conditions conducive to more homogeneous deformation compared to those promoting planar slip. On the other hand, for both slip conditions, WASPALOY**[33] exhibited intergranular fracture and sim-

**WASPALOY is a trademark of Precision Rings, Inc., Indianapolis,

ilar lives at $800^{\circ} \mathrm{C}$. It has been argued that homogeneous slip produces high average boundary stresses, giving rise to boundary failure in either initiation or propagation processes. Clavel et $a l^{[34]}$ attributed increased crack growth rates and intergranular fracture to the effects of planar slip in INCONEL 718 alloy. We believe that the intergranular

INCONEL is a trademark of INCO Alloys International, Inc., Huntington, WV.

cracking and associated reduction in life under conditions exhibiting homogeneous slip result from the simultaneous action of a more severe time-dependent process such as oxidation. However, homogeneous slip is more likely to govern life by enabling dislocation climb and cross slip, which are responsible for time-dependent strain accumulation. Time-dependent strain is manifested by the increased amount of inelastic strain in a cycle as the strain rate is decreased or the temperature is raised.

Even at the highest temperature and the lowest strain rate employed, the grain boundary damage due to creep was not observed, implying that the reduction in $N_{i}$ as a function of strain rate and temperature is not governed by the interaction of creep damage with fatigue. From several studies on austenitic stainless steels and superalloys, it has become apparent that the development of creep damage in a fatigue cycle depends not only on strain rate but also on cyclic loading pattern. ${ }^{[35-38]}$ In a balanced cycle with equal strain rates in tension and compression, similar to that employed in this study, it is considered that bulk intergranular creep damage produced in tension is reversed in compression and, hence, that no net damage can develop. Woodford and Coffin $^{[39]}$ have indicated that under balanced cycle conditions, creep cavities can occur only when the strain rate is below a certain critical value. From this observation, it is inferred that the strain rates employed in this study are in a regime where the creep damage is not expected to occur in balanced cycle conditions.

Irrespective of the cracking mode, oxidation exerted its influence over the entire strain rate regime at $850^{\circ} \mathrm{C}$ and at all temperatures at $\dot{\varepsilon}=4 \times 10^{-5} \mathrm{~s}^{-1}$. The detrimental effects of oxidation in fatigue can be attributed to (a) oxidation-assisted intergranular cracking and (b) accelerated transgranular crack initiation and propagation. At $850^{\circ} \mathrm{C}$ and $\dot{\varepsilon} \geq 4 \times 10^{-4} \mathrm{~s}^{-1}$, the transgranular crack paths showed extensive crack branching (Figure 14). At elevated temperatures and in the case of transgranular fracture, oxygen will diffuse along slip bands to enhance stage-I cracking or ahead of the crack tip to enhance stage-II type of growth. As observed in this study, at certain times, the crack initiation by stage-I mechanism is bypassed and the crack initiation takes place directly by stage-II mechanism (Figures 7 (a) and 14). The thin adherent oxide layer which forms during heating and equilibration time prior to the commencement of a test will act as a barrier to transgranular shear slip processes and will prevent the development of active shear slip bands in surface-connected grains that are responsible for stage-I cracking. Eventually, within a few cycles, surface oxide cracks and stage-II cracking quickly ensues. The oxide layer experiences a mechanical strain which can result from one or a combination of the following: (a) strain from the applied mechanical loading in the material, ${ }^{[40]}(\mathrm{b})$ the mismatch in the thermal expansion coefficients among the different stoichiometries of the oxide and substrate, ${ }^{[4] .42 .43]}$ (c) the load due to the volume difference between the substrate and various oxides, ${ }^{[44.45 .46]}$ and (d) relative creep behavior between the oxide and substrate. ${ }^{[43]} \mathrm{A}$ tensile strain in the fatigue cycle will cause the brittle oxide to fracture above some critical fracture strain. ${ }^{[47]}$ The tensile fracture strain for cracking the chromia scale on alloy $800 \mathrm{H}$ at $800{ }^{\circ} \mathrm{C}$ has been reported to be as low as 0.1 pct at a strain rate of $\approx 10^{-6} \mathrm{~s}^{-1}$ and to further decrease as the strain rate is increased. ${ }^{[48]}$ It has been found that tensile oxide fracture is especially detrimental for crack initiation and growth, because the repeated oxide fracture can channel crack growth into the substrate.

The influence of oxidation on crack initiation was clearly illustrated by Coffin ${ }^{[49]}$ and Solomon and Coffin ${ }^{[50]}$ in comparative experiments in air and vacuum at $816^{\circ} \mathrm{C}$ using A286 and UDIMET* 500. Fatigue life was higher in vac-

*UDIMET is a trademark of Special Metals Corporation, New Hartford, NY.

uum than in air, which was also shown for alloy $800 \mathrm{H}$ under symmetrical loading by Kempf et al. ${ }^{[51]}$ and by Bressers et al. ${ }^{[47]}$ The effect of oxidation in the transgranular fatigue cracking regime for alloy $800 \mathrm{H}$ has been estimated by Bressers et al. ${ }^{[46]}$ by comparing the crack initiation and propagation behavior in air with the behavior under vacuum over a range of strain rates at $800^{\circ} \mathrm{C}$. Their studies revealed 


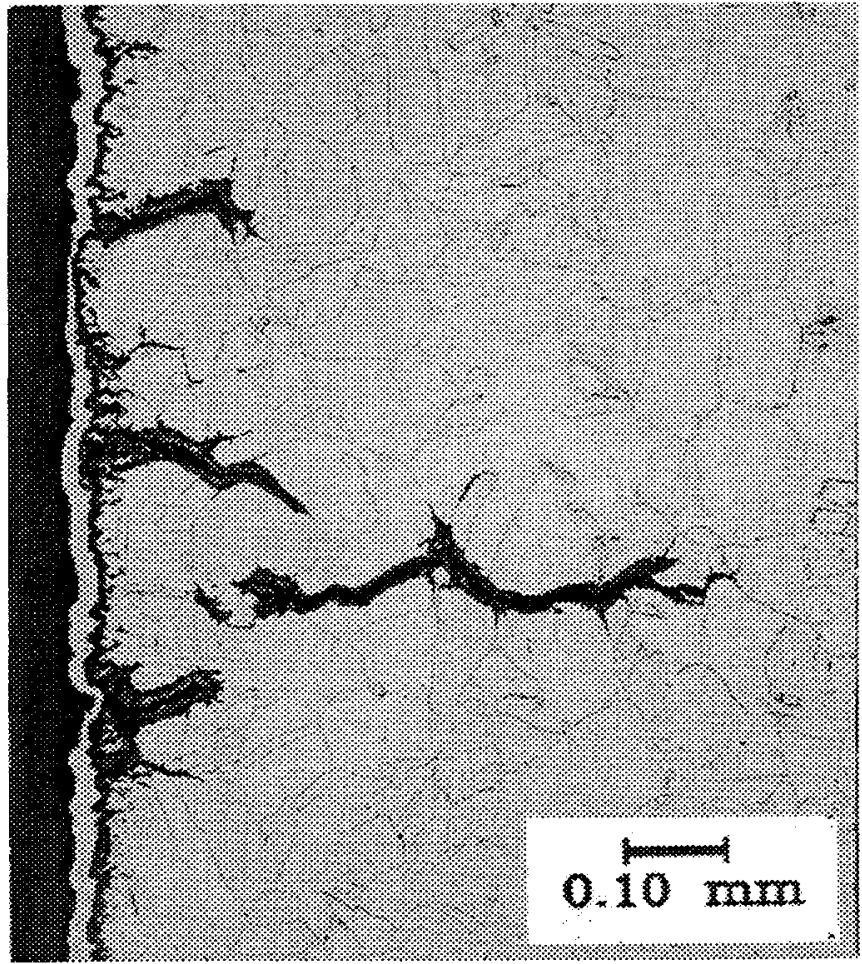

Fig. 16-Intergranular crack initiation in the surface oxide scales formed at $950^{\circ} \mathrm{C}, \dot{\varepsilon}=4 \times 10^{-5} \mathrm{~s}^{-1}$. It can be noted that the oxide scales on the crack flanks are porous.

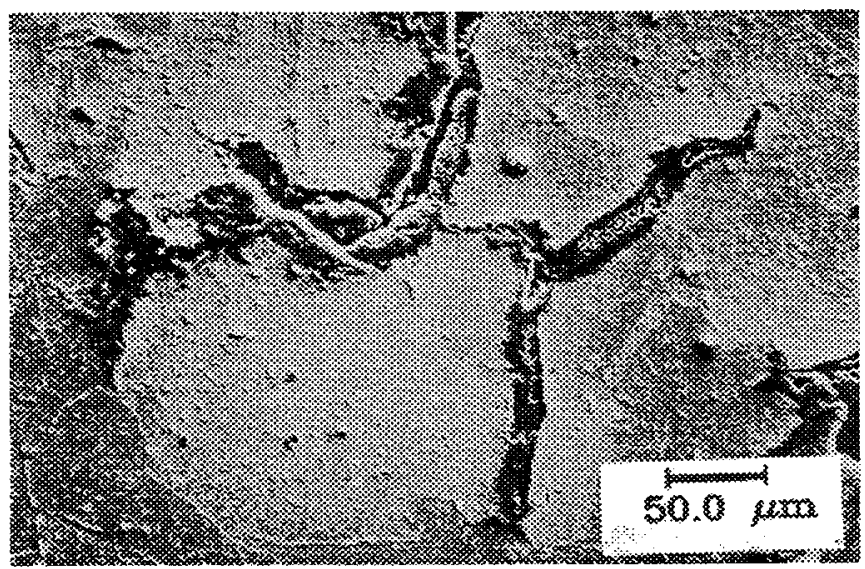

Fig. 17-Oxide scale along the intergranular fracture paths at $850^{\circ} \mathrm{C}, \dot{\varepsilon}$ $=4 \times 10^{-5} \mathrm{~s}^{-1}$. Internal oxidation could be seen by the sides of crack flanks.

that, besides the enhancement of crack nucleation, oxidation also speeds up the growth rate of microcracks by enhancing the growth rate of the individual cracks as well as through multiple crack coalescence. Evidence for oxidation-aided intergranular crack initiation and propagation at $950{ }^{\circ} \mathrm{C}$ is presented in Figures 16 and 7 (c), respectively. These figures clearly show appreciable oxide scale formation on the surface and along intergranular fracture paths. The absorption and inward diffusion of the oxygen atoms down the grain boundaries can cause reduction in the sur-
Fig. 18-Intergranular cavities ahead of the crack tip in the tests conducted at $850^{\circ} \mathrm{C}, \dot{\varepsilon}=4 \times 10^{-5} \mathrm{~s}^{-1}$. These cavities resulted due to the interaction between oxidation and grain boundary carbides.

face energy and, presumably, in the cohesive strength across the grain boundary.

For test conditions that promoted intergranular cracking, the oxidation process was initiated on those grain boundaries which are oriented approximately perpendicular to the loading axis (Figure 16). Crack initiation was revealed by the development of a crack in the surface oxide layer formed at the grain boundary (Figure 16). The rapid diffusion of oxygen along the grain boundaries caused internal oxidation in the vicinity and ahead of the microcracks (Figure 17). Recent studies on the fatigue crack initiation in oxide scales of alloy $800 \mathrm{H}$ at $800{ }^{\circ} \mathrm{C}$ revealed that the time of preoxidation decides the course of surface crack initiation and internal oxidation. ${ }^{[48]}$ It has been found that, in the initial stages, the rapid scale growth leads to $\mathrm{Cr}$ depletion in the subsurface regions, facilitating the formation of ironrich oxide scales. The nonexistence of chromia in oxide scale modifies its crack healing nature, making it nonprotective, and prevents the healing of oxide scale cracks. This has been found to cause increased internal oxidation along grain boundaries leading to the surface crack formation.

In this investigation, we have noticed occasionally large intergranular cavities ahead of the crack tip in the oxygenaffected regions because of the decohesion of carbides (Figure 18). It seems reasonable to suggest that the oxidation at the intergranular crack tip and the presence of cavities would render a thin layer of material more brittle and so would assist crack propagation. It is believed that the type of cavities shown in Figure 18 occur by the interaction of oxygen with grain boundary carbides. The oxygen reacting with the grain boundary carbides also enables the formation of $\mathrm{CO}$ and $\mathrm{CO}_{2}$ gas bubbles which act as cavity nuclei. ${ }^{27.52-55]}$ The large internal pressure introduced within the gas bubbles during the gas-forming reaction is considered to stabilize the nucleated cavities. ${ }^{[55]} \mathrm{Raj}^{[56]}$ predicted that an internal pressure as high as $1000 \mathrm{MPa}$ may occur during carbideoxidation interaction. The enhanced oxidation of the grain boundaries can be ascribed to the lattice mismatch at the grain boundary, which provides a path of easy diffusion for oxygen, and to the appreciable presence of oxidizable elements such as $\mathrm{Cr}$ and $\mathrm{Ti}$ at the grain boundary in the form of carbides. 


\section{SUMMARY}

1. The number of cycles to macrocrack initiation decreased with decreasing strain rate from $4 \times 10^{-3} \mathrm{~s}^{-1}$ to $4 \times 10^{-6} \mathrm{~s}^{-1}$ at $850^{\circ} \mathrm{C}$ and with increasing temperature from $750{ }^{\circ} \mathrm{C}$ to $950{ }^{\circ} \mathrm{C}$ at $\dot{\varepsilon}=4 \times 10^{-5} \mathrm{~s}^{-1}$.

2. Cyclic hardening and softening behaviors of the alloy were found to depend on temperature and strain rate conditions employed. A brief period of cyclic hardening followed by softening was observed at $750{ }^{\circ} \mathrm{C}$. At $850{ }^{\circ} \mathrm{C}, \dot{\varepsilon} \geq 4 \times 10^{-4} \mathrm{~s}^{-1}$, a well-defined saturation stage occurred after initial hardening. At $950{ }^{\circ} \mathrm{C}$ and $850^{\circ} \mathrm{C}, \dot{\varepsilon} \leq 4 \times 10^{-5} \mathrm{~s}^{-1}$, cyclic softening was found from the beginning.

3. Dynamic strain aging characterized by serrated flow was observed in the higher strain-rate tests at $850^{\circ} \mathrm{C}$. The effective pinning of dislocations by fine $\mathrm{M}_{23} \mathrm{C}_{6}$ particles occurred in the DSA regime.

4. The alloy deformed predominantly by planar slip at $750^{\circ} \mathrm{C}$. The accumulation of dislocations in planar slip bands and dislocation-precipitate interactions played an important role in dictating the course of cyclic stress response at $750{ }^{\circ} \mathrm{C}$. The cycling softening at $850{ }^{\circ} \mathrm{C}$ and $950{ }^{\circ} \mathrm{C}\left(\dot{\varepsilon} \leq 4 \times 10^{-5} \mathrm{~s}^{-1}\right)$ was found to have correlation with the occurrence of subgrains.

5. Under balanced cycle conditions employed in this study, LCF life is not governed by intergranular creep rupture damage mechanisms. Reduction in LCF life with increasing temperature and decreasing strain rate resulted from homogenization of slip and concomitant increase in inelastic strain generated in a cycle and partly from the intergranular crack initiation resulting from oxidation of surface-connected grain boundaries and rapid crack propagation through embrittled grain boundaries.

6. The test conditions that promoted cyclic hardening revealed massive precipitation of $\mathrm{M}_{23} \mathrm{C}_{6}$ on grain boundaries. This observation suggests that the alloy may be susceptible to intergranular corrosion in oxidizing environments due to the sharp decline in chromium concentration in the regions adjacent to the carbide lamellae.

\section{ACKNOWLEDGMENT}

One of the authors (KBSR) wishes to acknowledge the National Research Council for granting him a fellowship.

\section{REFERENCES}

1. J.B. Conway, J.T. Berling, and R.H. Stentz: Metall. Trans., 1972, vol. 3, pp. 1633-37.

2. J. Bressers, U. Schusser, R. De Cat, E. Fenske, and P. Tambuyser: Effects of the Time Dependent Processes on the Low Cycle Fatigue Behavior of Alloys, Project Cost 501, Report No. CCR 5: P/501/5/1/, Commission of the European Communities, Luxemberg, Mar. 1984.

3. C.E. Jaske, H. Mindlin, and J.C. Perrin: ASTM STP 520, 1973, pp. 365-76.

4. J. Bressers: Proc. Int. Conf. on High Temperature Alloys-Their Exploitable Potential, Oct. 15-17, 1985, CEC, Joint Research Centre, Petten, J.B. Marriot, M. Merz, J. Nihaul, and J. Ward, eds., Elsevier Applied Science, London, 1986, pp. 385-410.

5. A. Czyrska-Filemonowicz and K. Spiradeck: $Z$. Werkstofftech., 1983, vol. 14 , pp. $417-21$.
6. H.P. Degischer and H. Aigner: Proc. Int. Colloquium on Stainless Steels, Saint-Etienne, 1982, pp. 16-22.

7. U. Essman and H. Mughrabi: Phil. Mag., 1979, vol. 40, pp. 737-56.

8. D.J. Quesnel and J.C. Tsou: Mater. Sci. Eng., 1983, vol. 59, pp. 91-113.

9. A. Czyrska-Filemonowicz, P. Krautwesser, and P.J. Ennis: Applications in Materials Sciences., Proc. 13th Int. Congr. on Electron Microscopy, July 17-22, 1994, B. Jouffrey and C. Colliex, eds., Les Editions De Physique, Paris, 1994, vol. 2, pp. 33-34.

10. L.K. Singhal and J.W. Martin: Acta Metall., 1967, vol. 15, pp. 160310

11. A.A. Tavassoli and G. Colombe: Metall. Trans. A, 1978, vol. 9A, pp 1203-11.

12. H.F. Merrick: Metall. Trans., 1974, vol. 5, pp. 891-97.

13. D. Founier and A. Pineau: Metall. Trans. A, 1977, vol. 8A, pp. 1095-1105.

14. C.H. Wells and C.P. Sullivan: Trans. ASM, 1970, vol. 68, pp. $217-$ 26.

15. B.A. Lerch and V. Gerold: Acta Metall., 1985, vol. 33, pp. 1709-16

16. B.A. Lerch and V. Gerold: Metall. Trans. A, 1987, vol. 18A, pp. $2135-41$.

17. M. Valsan, K.B.S. Rao, M. Vijayalakshmi, S.L. Mannan, and D.H. Shastry: Metall. Trans. A, 1992, vol. 23A, pp. 1751-61.

18. M. Valsan, K. Bhanu Sankara Rao, and S.L. Mannan: Trans. Ind. Inst. Met., 1989, vol. 42, suppl., pp. 203-16.

19. C. Calabrese and C. Laird: Mater. Sci. Eng., 1974, vol. 13, pp. 14157.

20. C.E. Feltner and C. Laird: ASTM STP 467, 1970, pp. 77-112.

21. K.H. Chein and E.A. Starke, Jr: Acta Metall., 1975, vol. 23, pp. 117384.

22. K.B.S. Rao, H. Schiffers, H. Schuster, and H. Nickel: Metall. Trans. $A, 1988$, vol. 19A, pp. 359-71.

23. Hong Nahm and John Moteff: Metall. Trans. A, 1976, vol. 7A, pp. 1473-77.

24. R.E. Villigrana, J.L. Kaae, and J.R. Ellis: Metall. Trans. A, 1981, vol. $12 \mathrm{~A}$, pp. $1849-57$

25. M.E. Abd El-Azim, P.J. Ennis, H. Schuster, F.H. Hammand, and H. Nickel: The Tensile Properties of Alloy $800 \mathrm{H}$ and 617 in the Range 20 to $950^{\circ} \mathrm{C}$, Report No. Jul-2344, Kernforschungsanlage Juelich, Juelich, Germany, Jan. 1990.

26. R.A. Mulford and U.F. Kocks: Acta Metall., 1979, vol. 27, pp. 112534.

27. K. Bhanu Sankara Rao: Ph.D. Thesis, University of Madras, Madras, and IGCAR-Kalpakkam, Kalpakkam, India, Jan. 1989.

28. K. Bhanu Sankara Rao, M. Valsan, R. Sandhya, S.L. Mannan, and P. Rodriguez: Trans. Ind. Inst. Met., 1991, vol. 44, pp. 255-70.

29. K. Bhanu Sankara Rao, M. Valsan, R. Sandhya, S.L. Mannan, and P. Rodriguez: High Temp. Materials and Processes, 1986, vol. 7, pp. $171-77$

30. J. Bressers, L. Remy, and W. Hoffelner: Proc. Conf. High Temperature Alloys for Gas Turbines and Other Applications, Liegh, Oct. 6-9, 1986, W. Betz, ed., D. Reidel Publishing Co, Berlin, 1986, pp. $441-68$.

31. J. Bressers and M. Roth: Proc. ASME Int. Conf. on Advances in Life Prediction Methods, Albany, NY, Apr. 18-20, 1983, D.A. Woodford and J.R. Whitehead, eds., ASME, New York, NY, 1983, pp. 85-92.

32. S. Bashir and S.D. Antolovich: Superalloys 1984, Proc. 5th Int. Symp. on Superalloys, Oct. 7-11, 1984, Seven Springs Mountain Resort, Champion, PA, M. Gell, C.S. Kortovich, R.H. Bricknell, W.B. Kent, and J.F. Radavich, eds., TMS-AIME, Warrendale, PA, 1984, pp. 295307.

33. B.A. Lerch: Microstructure Effects on the Room and Elevated Temperature LCF Behavior of Waspaloy, NASA Contractor Report No. $165497,1982$.

34. M. Clavel, C. Levaillant, and A. Pineau: Creep-Fatigue-Environment Interactions, R.M. Peiloux and N.S. Stollof, eds., TMS-AIME, Warrendale, PA, 1980, pp. 24-45.

35. S.S. Manson, G.R. Halford, and R.E. Oldrieve: Relation of Cyclic Loading Pattern to Microstructural Fracture in Creep-Fatigue, NASA Technical Memorandum No. 83473, 1984

36. K. Bhanu Sankara Rao: Proc. Indo-German Seminar on Trends and Techniques in Modern Materials Research, Kalpakkam, Feb. 1987, Report No. 99C, IGCAR-Kalpakkam, Kalpakkam, India, 1988, pp. $81-92$.

37. D. Sidey and L.F. Coffin, Jr.: ASTM STP 675, 1979, pp. 528-68.

38. B.K. Min and R. Raj: ASTM STP 675, 1979, pp. 569-91. 
39. D.A. Woodford and L.F. Coffin, Jr.: Grain Boundaries in Engineering Materials, Proc. 4th Bolton Landing Conf., Lake George, NY, Claitors Publishing Division, Baton Rouge, LA, 1974, pp. 421-30.

40. R.W. Neu and H. Sehitoglu: Metall. Trans. A, 1989, vol. 20A, pp. 1755-67.

41. J.K. Tien, S.V. Nair, and V.C. Cardone: Flow and Fracture at Elevated Temperatures, R. Raj, ed., ASM, Metals Park, OH, 1985, pp. 179-214.

42. D. Bruce and P. Hancock: J. Inst. Met., 1969, vol. 97, pp. 148-55.

43. H. Riedel: Met. Sci., 1982, vol. 16, pp. 569-80.

44. N.B. Pilling and R.E. Bedworth: J. Inst. Met., 1933, vol. 29, pp. 52936.

45. A. Atkinson: Corros. Sci., 1982, vol. 22, pp. 347-57.

46. M. Schutze: Oxid. Met., 1985, vol. 24, pp. 199-232.

47. J. Bressers, U. Schusser, and B. Ilschener: Low Cycle Fatigue and Elasto-Plastic Behaviour of Metals, K.T. Rie, ed., Elsevier Applied Science, London, 1987, pp. 365-70.

48. J. Barbehon, A. Rahmel, and M. Schutze: Low Cycle Fatigue and
Elasto-Plastic Behavior of Metals, K.T. Rie, ed., Elsevier Applied Science, London, 1987, pp. 371-77.

49. L.F. Coffin, Jr.: Metall. Trans., 1974, vol. 5, pp. 1053-60.

50. H.D. Solomon and L.F. Coffin, Jr.: ASTM STP 520, 1973, pp. 112-22.

51. B. Kempf, K. Bothe, and V. Gerold: Fracture Control of Engineering Structures, Proc. Eur. Conf. on Fracture, ECF 6, H.C. Van Elst and A. Bakker, eds., EMAS, Warley, United Kingdom, 1986, vol. II, pp. 1129-35.

52. P. Rodriguez and K. Bhanu Sankara Rao: Progr. Mater. Sci., 1993, vol. 37 , pp. $403-80$.

53. R.H. Bricknell and D.A. Woodford: Metall. Trans. A, 1981, vol. 12A, pp. 425-33.

54. B.F. Dyson: Acta Metall., 1982, vol. 30, pp. 1639-46.

55. D.M.R. Taplin, N.Y. Tang, and H.H.E. Leipholz: Advances in Fracture Research, Proc. 6th Int. Conf. on Fracture, ICF6, New Delhi, India, Dec. 1984, S.R. Valluri, ed., Pergmon Press, Oxford, 1984, vol. 1, pp. 129-47.

56. R. Raj: Acta Metall., 1982, vol. 30, pp. 1259-68. 
